Check for updates

Cite this: RSC Adv., 2017, 7, 25753

Received 20th January 2017

Accepted 18th April 2017

DOI: $10.1039 / c 7 r a 00868 f$

rsc.li/rsc-advances

\section{2,3-Disubstituted-1,4-naphthoquinones containing an arylamine with trifluoromethyl group: synthesis, biological evaluation, and computational study $\dagger$}

\author{
Hatice Yıldırım, (D) *a Nilüfer Bayrak, (DD a Amac Fatih Tuyun, (D) *b Emel Mataracı Kara, ${ }^{\text {c }}$ \\ Berna Özbek Çelik ${ }^{c}$ and Girish Kumar Gupta (iD) ${ }^{d}$
}

\begin{abstract}
Antibacterial and antifungal organic compounds are becoming increasingly important for biomedical applications. This study deals with the synthesis, characterization of structures, in silico PASS prediction, and the discovery of antibacterial and antifungal properties based on new sulfanyl-1,4-naphthoquinone derivatives containing an arylamine with a trifluoromethyl group at different positions, which can be further applied in drug discovery and development. The in vitro antimicrobial potential of the newly synthesized compounds was evaluated in a panel of seven bacterial strains (three Gram-positive and four Gram-negative bacteria) and one yeast, with an additional study on antibiofilm activities. The compounds ( $5 \mathrm{~b}$ and $5 \mathrm{e}$ ) were identified as having strong antibacterial efficiency against the human-originated pathogen S. epidermidis, with minimal inhibitory concentration values $\left(4.88\right.$ and $2.44 \mu \mathrm{g} \mathrm{mL}{ }^{-1}$, respectively). The toxicity of both compounds ( $5 \mathrm{~b}$ and $5 \mathrm{e}$ ) was studied in detail to compare these compounds with Cefuroxime (a clinically proven drug). The antibacterial activity of the compound $5 \mathrm{f}$ was equal to that of Cefuroxime. Moreover, three compounds (5b, $5 \mathrm{e}$, and $5 \mathrm{f}$ ) exhibited excellent antibacterial activity, and $5 \mathrm{~b}$ and $5 \mathrm{e}$ were two and four times more active than the reference antimicrobial compound (Cefuroxime), respectively. For this reason, these three compounds (5b, 5e, and 5f) are being considered as promising antibacterial agents. In addition, docking studies were used to better rationalize the action and prediction of the binding modes of these compounds.
\end{abstract}

\section{Introduction}

Although there has been a decline in the incidence of infectious diseases, there is no place in the world where infectious diseases are an insignificant cause of illness and death. ${ }^{1,2}$ The number of deaths caused by pathogens and parasites have shown a minor decline of only $1 \%$ per year. Over 10 million people have died from infections since $1990 .^{1 a, 2}$ The World Health Organization (WHO) estimates 13 million deaths from infectious diseases in $2050 .^{2}$ People in low- and middle-income countries suffer from diseases such as HIV/AIDS, tuberculosis,

${ }^{a}$ Chemistry Department, Engineering Faculty, Istanbul University, Avcilar, 34320, Istanbul, Turkey. E-mail: hyildirim@istanbul.edu.tr; Fax: +90 212473 7180; Tel: +90 2124737070

${ }^{b}$ Engineering Sciences Department, Engineering Faculty, Istanbul University, Avcilar, 34320, Istanbul, Turkey.E-mail: aftuyun@gmail.com; aftuyun@istanbul.edu.tr; Fax: +90 212473 7180; Tel: +90 2124737070

'Pharmaceutical Microbiology Department, Pharmacy Faculty, Istanbul University, Beyazit, 34116, Istanbul, Turkey

${ }^{d}$ Department of Pharmaceutical Chemistry, Maharishi Markandeshwar College of Pharmacy, Maharishi Markandeshwar University, Mullana, Ambala 133207, Haryana, India

† Electronic supplementary information (ESI) available. See DOI: $10.1039 / \mathrm{c} 7 \mathrm{ra00868f}$ malaria, other pathogens, and infections that have been causing the majority of deaths since $2010 .^{1 a, 2}$

Infectious diseases are among the most serious threats of the "top global health risk factors", just like the high risk factors of chemical spills and nuclear accidents. ${ }^{1 b, c, 2,3}$ WHO has, therefore, provided effective global strategies for the control of major infectious diseases that are being dubbed as the "infectious diseases control programs", which are necessary in order to help build these health systems. ${ }^{4}$

The fact that the resistance of bacterial and fungal pathogens leads to an ever-increasing global public health threat reflects the widespread and growing demand for new antibacterial and antifungal compounds, which are among the most prevalently used drugs. ${ }^{5}$ Unfortunately, very few new classes of antibacterial drugs have been registered for clinical practice in the past 50 years. ${ }^{6}$ Not surprisingly, this has recently caused a rapidly growing interest in the synthesis of new and efficient antibacterial and antifungal compounds that may be drug candidates for reducing infections caused by pathogens. ${ }^{7}$

The antimicrobial activities of an increasing number of quinone compounds are being investigated for the discovery of new antibacterial and antifungal compounds. ${ }^{7,8}$ A series of sulfanyl-1,4-naphthoquinone derivatives was synthesized and potent antifungal activity was exhibited in vitro by one 
compound, compared to the clinically proven antifungal drug fluconazole, against $S$. schenckii, and the clinically proven drug amphotericin-B against $T$. mentagraphytes. ${ }^{9}$ 1,4-Naphthoquinones containing an amino group have been used as antibacterials, antimalarials, antituberculars, larvicides and molluscicides, herbicides, and fungicides in many medical and biological applications. ${ }^{\mathbf{1 0 - 1 4}} \mathrm{A}$ series of phenylamino-1,4naphthoquinones was synthesized to investigate their antitumor effects against cancer cell lines and healthy fibroblasts, and it was reported that the presence of a chlorine atom in the acceptor quinone nucleus and/or the presence of a methyl group at the nitrogen atom of the donor phenylamino group induced changes in cytotoxic activity. ${ }^{15}$

Since the trifluoromethyl group $\left(-\mathrm{CF}_{3}\right)$ is one of the most important substituents in organic chemistry because of its interesting stereoelectronic profile, ${ }^{16}$ our attention was turned to the naphthoquinone compounds containing the $-\mathrm{CF}_{3}$ on the arylamines at the $o$-, $m$-, and $p$-positions, in light of previous studies. ${ }^{17}$ The $-\mathrm{CF}_{3}$ has an effect based on the different electron density distributions on the reactivity of the molecule. The efficiency of $-\mathrm{CF}_{3}$ on the physiological activity is a very significant topic in pharmaceutical studies. The physiological profile is dependent on the position of $-\mathrm{CF}_{3}$ within the bioactive molecules. ${ }^{\mathbf{1 6}}$

A series of naphthoquinone derivatives has been synthesized and tested for their biological activity against human African trypanosomiasis, normally known as sleeping sickness, a dangerous and often ignored parasitic disease. ${ }^{17}$ The activities of some compounds have been compared to evaluate the importance of the position of the $-\mathrm{CF}_{3}$ group on the phenyl amine ring and its substitution that caused by the inhibition of T. brucei cell proliferation. Compounds shown in Fig. 1 with $-\mathrm{CF}_{3}$ (electron withdrawing group) at different positions on the phenyl amine ring showed $T$. brucei inhibitory activity with average cytotoxicity. It was found that the presence of a chlorine atom instead of a second arylamine led to an increase in the activity. Additionally, changing the $-\mathrm{CF}_{3}$ from the para position to the ortho position led to an increase in the activity. It was reported that the reason for this enhancement in T. brucei inhibitory activity might have been the strong electron withdrawing groups $\left(-\mathrm{CF}_{3},-\mathrm{NO}_{2}\right.$, and $\left.\mathrm{Cl}\right)$ within the structure; replacing the $-\mathrm{CF}_{3}$ with the methyl group at different positions led to activity loss. In this study, it can be clearly seen that the substitution patterns $\left(2^{\text {nd }}\right.$ and $4^{\text {th }}$ positions) on aniline and monoamino- or diamino-substituted compounds affect the $T$. brucei inhibitory activity. ${ }^{17}$

Sulfanyl aminonaphthoquinone and aminonaphthoquinone derivatives have important applications in medicinal chemistry as biologically active substances. Among them, some most striking examples are shown in Fig. 2. Tandon et al. reported the synthesis of some sulfanyl aminonaphthoquinone compounds (I-IV) and their biological evaluation. Some of these compounds showed significant antibacterial activity. ${ }^{7 c, d}$ Very recently, another research study on the synthesis of the sulfanyl arylamino quinone compounds was reported by Ryu et al. Some of the tested compounds ( $\mathrm{V}$ and VI) completely inhibited fungal growth when compared to the Candida species. ${ }^{8 a}$ Tandon et al.

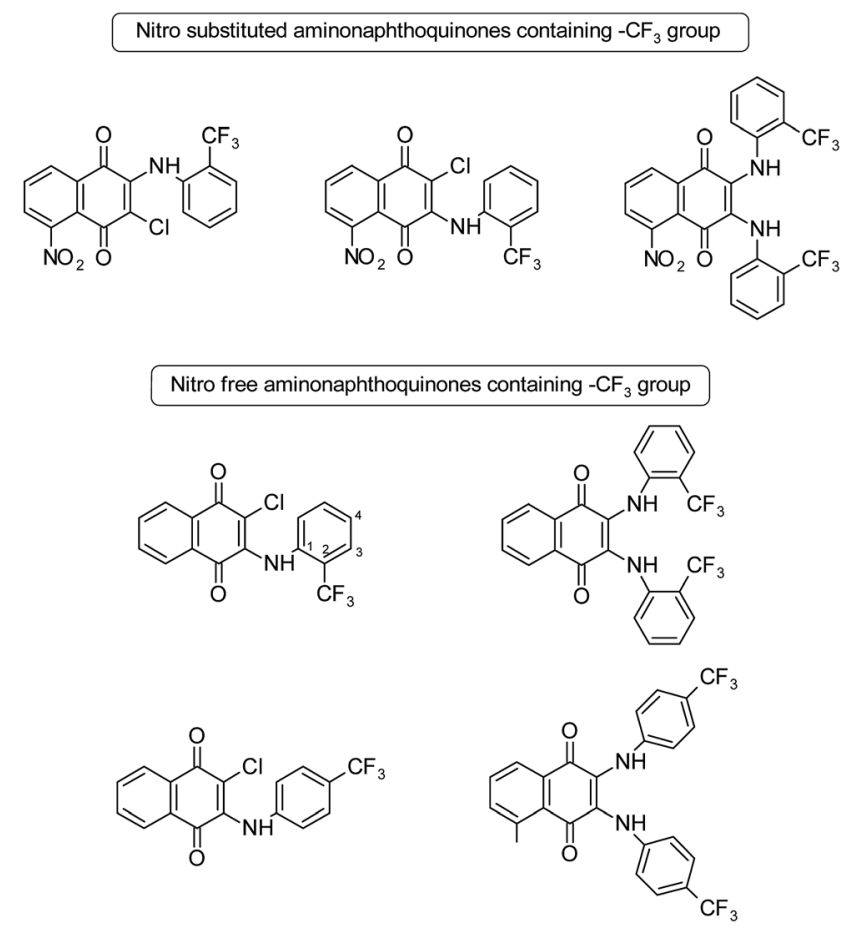

Fig. 1 Structures of some nitro free and nitro substituted aminonaphthoquinones. ${ }^{17}$

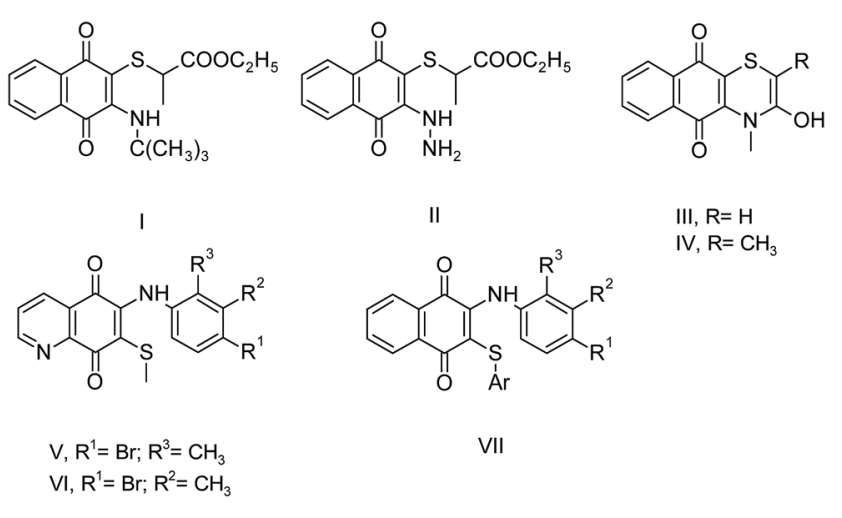

Fig. 2 Structures of some important sulfanyl aminonaphthoquinones with biological activity in literature.

synthesized other series of sulfanyl aminonaphthoquinone and aminonaphthoquinone derivatives, and the synthesized compounds were tested for antibacterial and antifungal activities. Particularly, sulfanyl aminonaphthoquinone derivatives containing the arylsulfanyl group did not exhibit any significant activity (VII). In this study, the antifungal activity was observed to decrease when the 2,3-disubstituted moiety was altered by the phenyl group. ${ }^{8 b}$

There are several factors that affect the biological evaluation of the quinone structures, which are listed as follows: (a) a naphthoquinoidal moiety; (b) an aromatic ring such as aniline; (c) the presence and position of substituents on the phenyl amine ring, and insertion of additional electronegative atoms (Cl, S, N etc.). ${ }^{15,17,18}$ Encouraged by all these facts, and in 


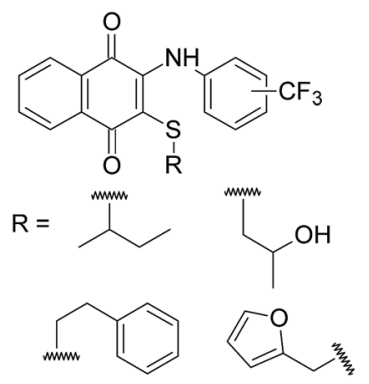

Fig. 3 Structures of the sulfanyl derivatives of 1,4-naphthoquinone based on aryl amines containing $-\mathrm{CF}_{3}$ group.

order to continue our previous studies, which were mainly about the synthesis of biologically active 1,4-naphthoquinone structures, we chose our compounds by (i) using sulfanyl derivatives of arylamino-1,4-naphthoquinone as the core structure; (ii) using arylamine ring containing the $\mathrm{CF}_{3}$ group at different positions ( $o-, m$-, and $p$-); (iii) using different types of thiols, as shown in Fig. 3. From this point of view, profound pharmacological effects of related compounds in previous studies gave us clues regarding the synthesis, characterization, and evaluation of some new sulfanyl-1,4-naphthoquinone derivatives containing an arylamine with the $-\mathrm{CF}_{3}$ at different positions, as antimicrobial agents.

\section{Results and discussion}

\subsection{The synthesis of substituted naphthoquinones}

Herein, the synthesis of 3-arylamino-1,4-naphthoquinone derivatives (3a-c) was carried out via the reactions of 2,3dichloro-1,4-naphthoquinone (1) and primary arylamines (2a-c) containing an electron withdrawing substituent $\left(-\mathrm{CF}_{3}\right)$ on the rings at the $o-, m$-, and $p$-positions as the starting materials in different mediums. ${ }^{17,19,27}$ Unlike the synthesis of $\mathbf{3 a}$ and $\mathbf{3 b}$ reported previously in the scientific literature, compound $3 \mathbf{c}$ was obtained in low yields in DMF in the presence of $\mathrm{K}_{2} \mathrm{CO}_{3}(10 \%)$. The synthesis of new sulfanyl 1,4-naphthoquinone derivatives containing an arylamine with the $-\mathrm{CF}_{3}$ at different positions $(\mathbf{5 a}-\mathbf{k})$ was achieved at room temperature via the reaction of 3arylamino-1,4-naphthoquinone derivatives $(\mathbf{3 a - c})$ with a variety of thiols (4a-d) in $\mathrm{CH}_{2} \mathrm{Cl}_{2}$ in the presence of $\mathrm{Et}_{3} \mathrm{~N}$ (1.1 eq.) as a base (shown in Scheme 1) in high yields. ${ }^{8}$ Additionally, compound 6 was obtained as a side-product from the reaction of 2-chloro-3-((4-(trifluoromethyl)phenyl)amino)naphthalene1,4-dione (3a) with butane-2-thiol (4a). Among the synthesized compounds, the sulfanyl 1,4-naphthoquinone derivatives (5a-k) and the side product (6) are new, while the arylamino-1,4naphthoquinone derivatives (3a-c) have been reported in earlier studies. ${ }^{17,19,27}$ New sulfanyl 1,4-naphthoquinone derivatives containing an arylamine with the $-\mathrm{CF}_{3}$ at different positions (5a-k) were obtained in the range of $30-85 \%$ yield as orange and red powders or oils. Spectroscopic methods like one dimensional NMR techniques $\left({ }^{1} \mathrm{H},{ }^{13} \mathrm{C}\right)$, FTIR spectra and mass spectrometry were applied to confirm the structures of obtained compounds. The FTIR spectra of $5 \mathbf{a}-\mathbf{k}$ and $\mathbf{6}$ showed some characteristic absorptions around $3275-3346 \mathrm{~cm}^{-1}(\mathrm{NH}), 1657-$ $1676 \mathrm{~cm}^{-1}(\mathrm{C}=\mathrm{O}), 3419-3433(\mathrm{OH}) \mathrm{cm}^{-1}, 2851-2978 \mathrm{~cm}^{-1}$ $\left(\mathrm{CH}_{\text {aliphatic }}\right)$ and $3024-3076 \mathrm{~cm}^{-1}\left(\mathrm{CH}_{\text {aromatic }}\right)$. The ${ }^{1} \mathrm{H}$ NMR spectra of $5 \mathbf{a}-\mathbf{k}$ and $6\left(\mathrm{CDCl}_{3}-d_{1}\right)$ exhibited the $\mathrm{NH}$ signal as a singlet between 7.64-7.93 ppm in the aromatic region and at 5.86-8.09 ppm corresponding to the aromatic protons. The signals associated with the other functional groups all appeared in the expected regions. Outstandingly, the presence of two peaks for the carbonyl groups $(-\mathrm{C}=\mathrm{O})$ in ${ }^{13} \mathrm{C}$ NMR spectra was the proof of the two substituents (amino and sulfanyl groups) attached to the naphthoquinone core. There was only one peak for the carbonyl group in the ${ }^{13} \mathrm{C}$ NMR spectrum of compound 6 because of the symmetry.

\subsection{The prediction of biological activity based on spectra}

The prediction of biological activity based on the spectral analysis of the synthesized compounds in the present communication was easily carried out by using the freely available website with the internet version of PASS and PharmaExpert: http://www.pharmaexpert.ru/PASSOnline/. ${ }^{20,21}$ The activity spectrum for a molecule is a list of biological activity for which the probability of the compound being active $\left(P_{\mathrm{a}}\right)$ and the probability of the compound being inactive $\left(P_{\mathrm{i}}\right)$ are calculated. $P_{\mathrm{a}}$ and $P_{\mathrm{i}}$ values are independent and their values vary from 0 to 1. For example, the PASS prediction results for one of the compound (5e) are summarized in Table 1.

It was found that for antibacterial and anti-infective activity, the compounds had $P_{\mathrm{a}}$ nearly equal to 0.2 . These findings also showed some good experimental results and can be considered to be valuable while planning the experiment, but some important factors should be taken into account such as the particular interest in some kind of activity, desirable novelty, the available facilities for experimental testing, etc.

\subsection{The antimicrobial activity}

All the newly synthesized sulfanyl 1,4-naphthoquinone derivatives containing an arylamine with the $-\mathrm{CF}_{3}$ at different positions (5a-k) and 2,3-disulfanyl 1,4-naphthoquinone (6) were evaluated for their in vitro antibacterial and antifungal activities. The antimicrobial assay results for all the newly synthesized 1,4-naphthoquinone structures (5a-k and $\mathbf{6}$ ) are given in Table 2.

In vitro activities of the studied molecules against planktonic cells are summarized in Table 2. Concerning the antibacterial activity, the results revealed that some compounds displayed varying effects on the growth of the tested Gram-positive and Gram-negative bacterial strains. As indicated in Table 2, among the synthesized compounds of $\mathbf{5 b} \mathbf{b} \mathbf{g}$ and $\mathbf{6}$, they generally showed potent antibacterial activity against some pathogenic strains that were tested. Actually, the activities of compounds $\mathbf{5 b}$ and $\mathbf{5 e}$ were superior as compared to that of Cefuroxime: $\mathbf{5 b}$ and 5e completely inhibited the growth of $S$. epidermidis, and were tested at the MIC level of 4.88 and $2.44 \mu \mathrm{g} \mathrm{mL} \mathrm{m}^{-1}$, respectively. In addition to these, the activity of compound $\mathbf{5} \mathbf{f}$ was equal to that of Cefuroxime. In general, most of the tested compounds showed better antibacterial activity against the Gram-positive 


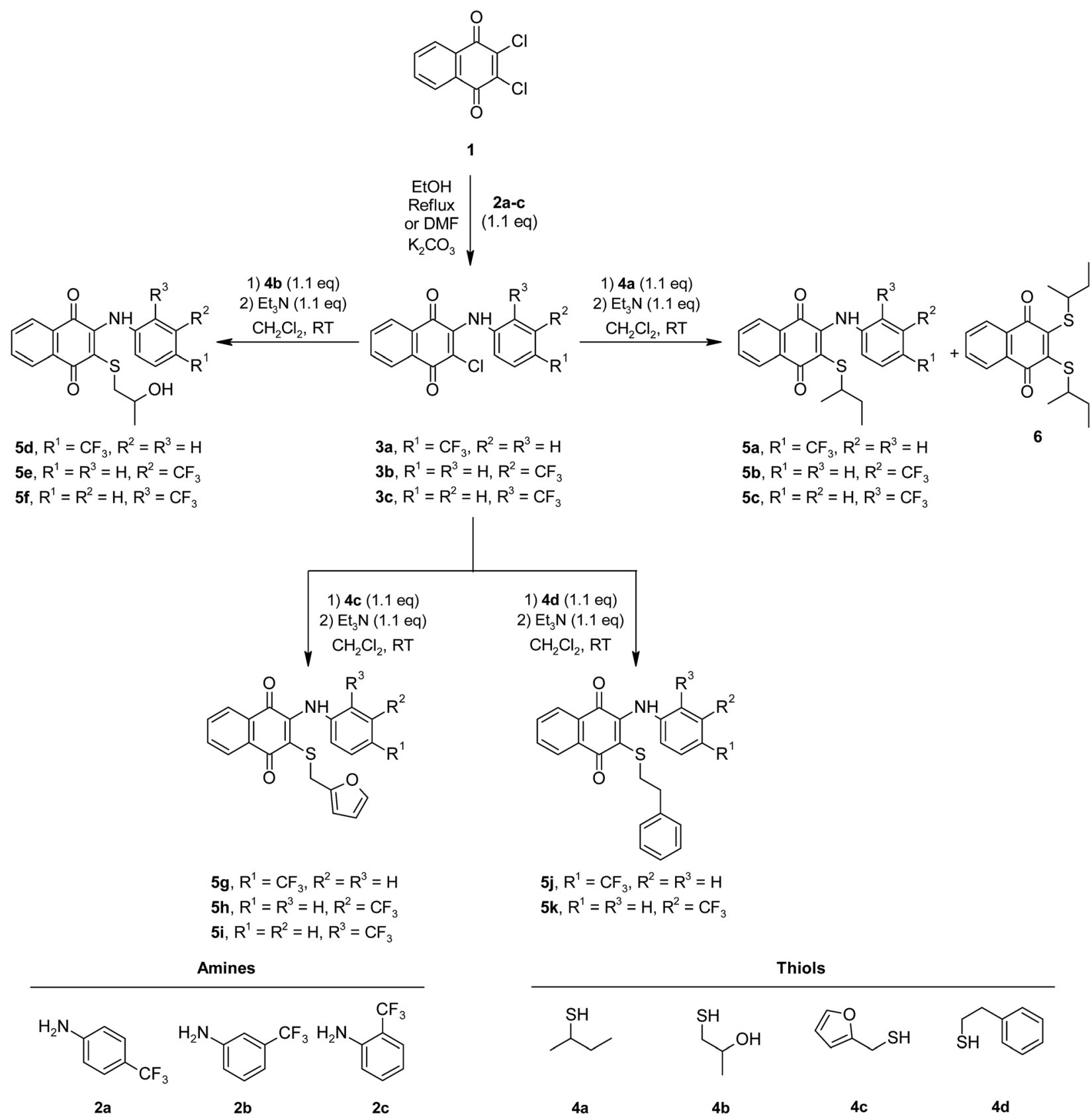

Scheme 1 Synthetic pathway for the preparation of new sulfanyl 1,4-naphthoquinone derivatives substituted with arylamines containing the $-\mathrm{CF}_{3}$ at $0-, m-$, and $p$-positions.

bacteria compared to the Gram-negative ones. The results revealed that compounds $\mathbf{5} \mathbf{d}$ and $\mathbf{5 g}$ exhibited moderate activity against Gram-positive bacteria. The test-cultures $P$. aeruginosa, $E$. coli, and $S$. aureus appeared non-effective to most of the synthesized compounds. Some of the synthesized compounds (5d-e, $\mathbf{5} \mathbf{g}$ and $\mathbf{5 j}$ ) possessed activity against $E$. faecalis, which had MIC values between $312.5-625 \mu \mathrm{g} \mathrm{mL}^{-1}$. In addition to $E$. faecalis, the compounds (5d and $\mathbf{5 g}$ ) possessed activity against $S$. epidermidis, which had the MIC value of $156.2 \mu \mathrm{g} \mathrm{mL}{ }^{-1}$. 2,3Disulfanyl 1,4-naphthoquinone (6) was only able to induce appreciable growth inhibitory activity against $S$. epidermidis, which had the MIC value of $78.12 \mu \mathrm{g} \mathrm{mL} \mathrm{m}^{-1}$. The compounds (5a-b, 5e-f, and $\mathbf{5 h}-\mathbf{k})$ exhibited no antibacterial activity against the Gram-negative bacteria. Regarding the antifungal activity of the tested compounds, only 2 compounds ( $5 \mathbf{j}$ and $\mathbf{5 k}$ ) were able to induce appreciable growth inhibitory activity against $C$. albicans.

To evaluate the importance of the position of the $-\mathrm{CF}_{3}$ on the phenyl amine ring with respect to the biological efficiency, the activities of all the synthesized compounds were compared (Scheme 1). The decrease in the antibacterial activities of the compounds with the $-\mathrm{CF}_{3}$ at the $p$-positions on the phenylamine ring, (5a, $\mathbf{5 d}, \mathbf{5} \mathbf{g}$, and $\mathbf{5 j}$ ) was the proof of an important factor for the antibacterial activity. In terms of the structure- 
Table 1 PASS prediction results for compound (5e)

\begin{tabular}{lll}
$P_{\mathrm{a}}$ & $P_{\mathrm{i}}$ & Activity \\
\hline 0.625 & 0.042 & TP53 expression enhancer \\
$\mathbf{0 . 5 8 9}$ & $\mathbf{0 . 0 9 4}$ & Membrane permeability inhibitor \\
0.426 & 0.027 & Pyruvate decarboxylase inhibitor \\
0.336 & 0.001 & CDC25 phosphatase inhibitor \\
0.285 & 0.201 & Aspartyltransferase inhibitor \\
$\mathbf{0 . 2 3 3}$ & $\mathbf{0 . 1 7 3}$ & Anti-infective \\
0.173 & 0.070 & Protein synthesis inhibitor \\
0.179 & 0.144 & Phosphatidylcholine-sterol $O$-acyltransferase inhibitor \\
$\mathbf{0 . 1 5 8}$ & $\mathbf{0 . 0 4 5}$ & Antibacterial, ophthalmic \\
$\mathbf{0 . 1 3 8}$ & $\mathbf{0 . 0 2 5}$ & Antibiotic anthracycline-like
\end{tabular}

activity relationship, the sulfanyl 1,4-naphthoquinone derivatives containing an arylamine with the $-\mathrm{CF}_{3}$ at the $m$-positions $(\mathbf{5 b}, \mathbf{5 e}, \mathbf{5 h}$, and $\mathbf{5 k})$ showed, in general, more potent antibacterial activities than the other sulfanyl 1,4-naphthoquinone derivatives with an arylamine containing the $-\mathrm{CF}_{3}$ at the $p$-positions $(\mathbf{5 a}, \mathbf{5 d}, \mathbf{5 g}$, and $\mathbf{5 j}$ ). The sulfanyl 1,4-naphthoquinone derivatives containing an arylamine with the $-\mathrm{CF}_{3}$ at the $o$-positions $(\mathbf{5 c}, \mathbf{5 f}$, and $\mathbf{5 i})$ showed, in general, more potent antibacterial activity than other sulfanyl 1,4-naphthoquinone derivatives with an arylamine containing the $-\mathrm{CF}_{3}$ at the $p$-position, but unfortunately, not better than other sulfanyl 1,4-naphthoquinone derivatives with an arylamine containing the $-\mathrm{CF}_{3}$ at the $m$-positions. The replacement of a halogen with the different types of sulfanyl derivatives led to variable types of activities. However, aliphatic substitutions like sec-butylthio and 2-hydroxypropylthio moieties of the compounds $(\mathbf{5 b}-\mathbf{f})$ in comparison to aralkyl or heteroaryl substitutions $(\mathbf{5 g}, \mathbf{5 h}$, and $\mathbf{5 k}$ ) may contribute partially toward biological potency with the additional effect of the position of $-\mathrm{CF}_{3}$. Moreover, this particular modification does not significantly affect the antifungal activity. Indeed, the aralkyl derivatives ( $\mathbf{5} \mathbf{j}$ and $\mathbf{5 k}$ ) showed moderate inhibition effect against $C$. albicans; this leads to the conclusion that the moiety may be a factor affecting the antimicrobial activity of the synthesized sulfanyl 1,4-naphthoquinone derivatives. In this study, when the in vitro antimicrobial activities of all the newly synthesized sulfanyl 1,4-naphthoquinone derivatives were investigated, three molecules (5b, 5e, and $\mathbf{5 f}$ ) had strong antibacterial efficiencies against $S$. epidermidis, which is usually considered as a common human originated pathogen.

The cytotoxic effects of the two compounds (5b and $\mathbf{5 e}$ ) were obtained as the $\mathrm{IC}_{50}$ values, which represent the molar drug concentrations required to cause $50 \%$ inhibition of cell viability. Consequently, all tested compounds significantly induced dose-dependent loss of viability in HepG2 cells after $24 \mathrm{~h}$. The $\mathrm{IC}_{50}$ values (5b: $19.54 \mu \mathrm{g} \mathrm{mL}{ }^{-1}, 5 \mathrm{e}: 10.18 \mu \mathrm{g} \mathrm{mL}^{-1}$ ) for the compounds were four times higher than the MIC results shown in Fig. 4 and 5.

\subsection{Antibiofilm activity}

A biofilm is a community of microbes embedded in a selfproduced polymeric matrix, which adheres to a surface.

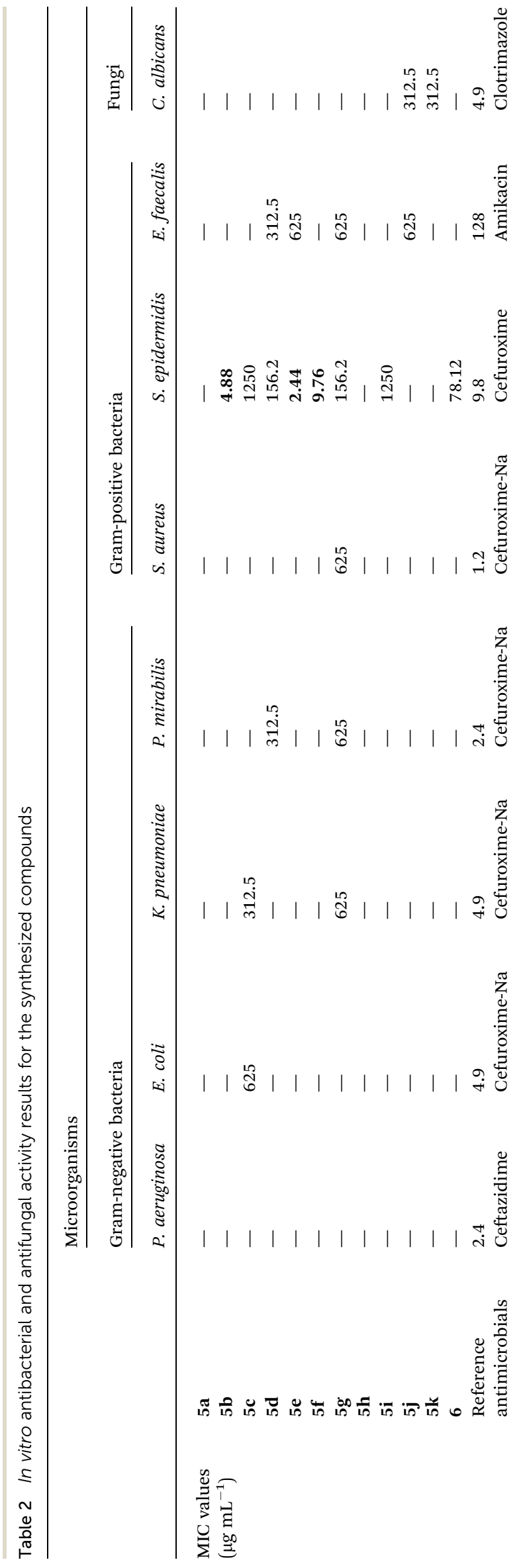




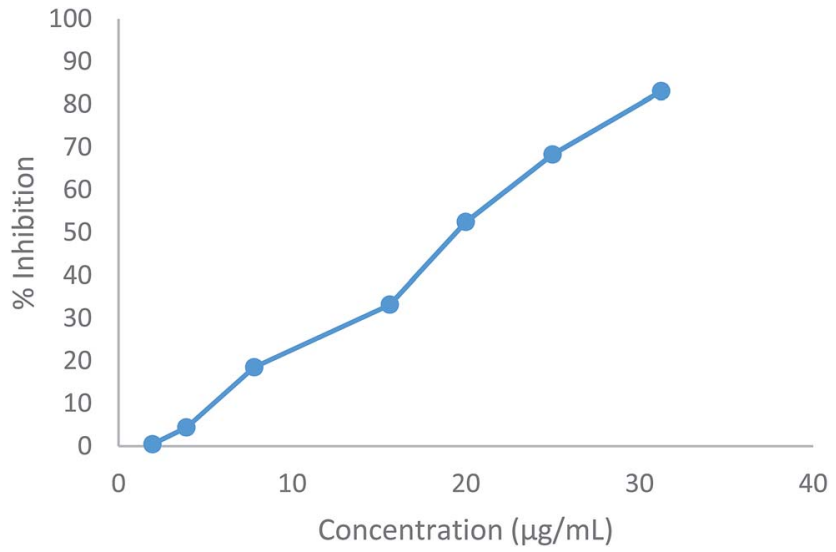

Fig. 4 The effect of the compound $5 b$ on the $\%$ inhibition at different concentrations.

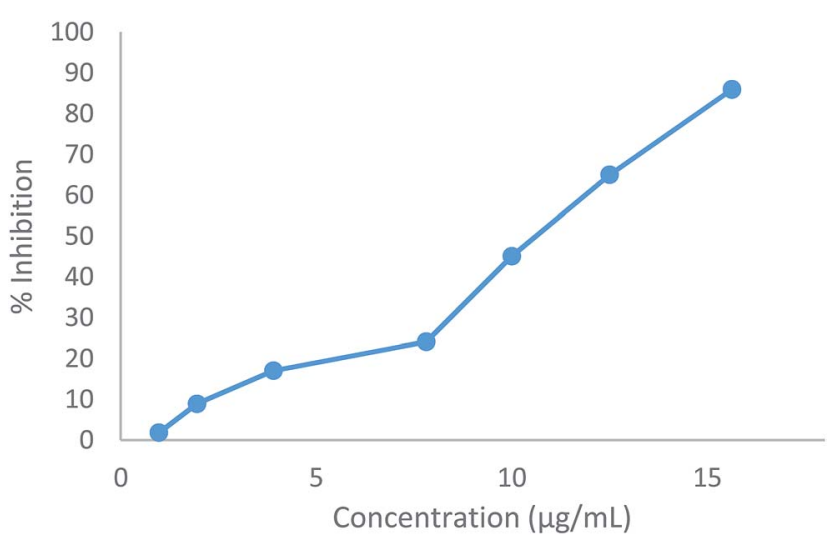

Fig. 5 The effect of the compound $5 \mathrm{e}$ on the $\%$ inhibition at different concentrations.

Microbial cells that grow in biofilms behave quite differently from their planktonic counterparts. The bacteria on the biofilm structures are protected from the environmental conditions, antimicrobial agents, and host immune responses, and the biofilm organisms are far more resistant to antimicrobial agents than the organisms in the suspension (up to 1000-fold increase). ${ }^{22}$

When we considered the antibiofilm activities of the antibacterial molecules $\mathbf{5 b}$ and $\mathbf{5 e}$ against the $S$. epidermidis biofilms, the MBEC values were 5000 and $1250 \mu \mathrm{g} \mathrm{mL}{ }^{-1}$, respectively. The MBEC/MIC ratio, which is one of the important parameters for choosing antibiotics in the treatment of biofilm associated infections, was found to be 1024 and 512 fold, respectively, in contrast to many antibiotics (up to 10000 fold). ${ }^{22 a}$

Since the only biofilm susceptible to the studied active molecules was $S$. epidermidis, both the biofilm attachment and inhibition of the biofilm formation assays were performed. When these tests were carried out, $\mathbf{5 b}$ inhibited the biofilm attachment according to the time, and it showed a significant inhibition activity against the biofilm formation at the $24^{\text {th }}$ hour according to its varying concentrations (Fig. 6). In contrast to these findings, there was an inhibition in the biofilm attachment of $\mathbf{5 e}$ at the end of the $2^{\text {nd }}$ hour; following that, as the number of cells increased within the environment, this activity was decreased at the $4^{\text {th }}$ hour.

The biofilms are not affected by "therapeutically achievable concentrations" of antimicrobial agents. The antibiofilm therapies are generally focused on the inhibition of the biofilm formation. ${ }^{22 b}$ For this purpose, the inhibitions of bacterial attachment to the surfaces were investigated; the inhibition of the biofilm production at the MIC or subMIC values of molecules were investigated as well. $\mathbf{5 b}$ and $\mathbf{5 e}$ were able to inhibit the attachment of bacteria at the MIC or subMIC values, and the biofilm formation after 24 hours was approximately $50 \%$ (at $1 /$ $10 \times$ MIC $p<0.001$ ). Since inhibiting a mature biofilm can be very difficult, the inhibition of the biofilm formation in the early stages may seem to be more applicable and advantageous.

\subsection{Docking studies}

In silico approaches like docking studies are currently gaining much attention to pre-access the probable mechanism for the action and design of new templates towards more potential antibacterial agents. ${ }^{21 f}$ The significant experimental
A

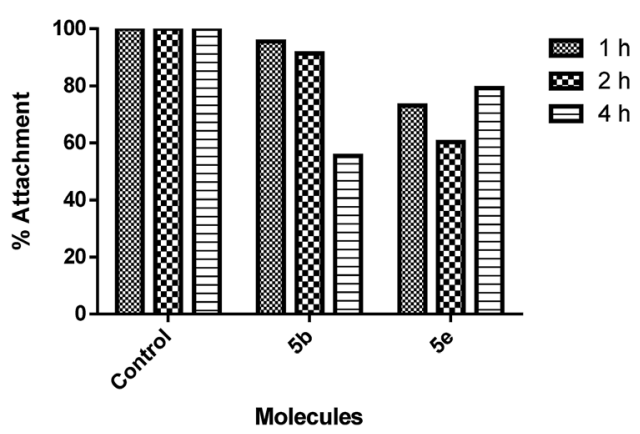

B

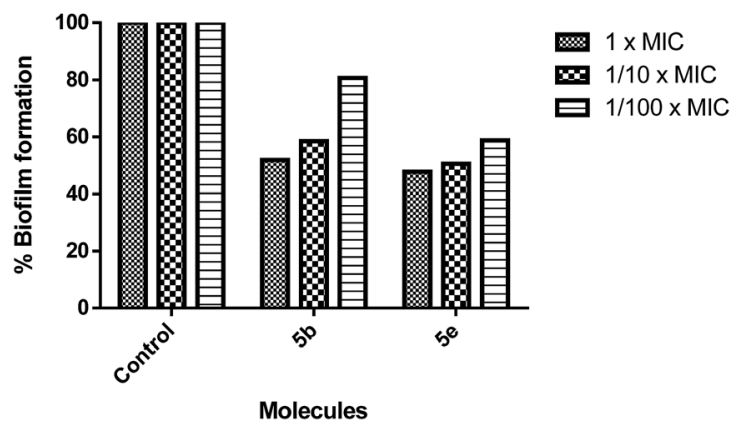

Fig. 6 The inhibition of S. epidermidis. (A) The surface attachment to the wells containing $1 / 10 \times$ MIC of molecules and an inoculum of $1 \times 10^{7}$ cfu per $200 \mu \mathrm{L}$, incubated for 1,2 , or $4 \mathrm{~h}$ at $37^{\circ} \mathrm{C}$. (B) The biofilm formation in each well containing $1 \times, 1 / 10 \times$, or $1 / 100 \times$ MIC of molecules and an inoculum of $5 \times 10^{5} \mathrm{cfu}$ per $200 \mu \mathrm{L}$, incubated for $24 \mathrm{~h}$ at $37^{\circ} \mathrm{C}$. The control bars indicating bacteria without the molecule of interest are accepted as $100 \%$. Six wells were used for each molecule. Each experiment is representative of the two independent tests, and the error bars indicate the standard deviations. All the differences between the control and molecule-treated biofilms are statistically significant $(p<0.001)$. 
antibacterial activities of the compounds $\mathbf{5 b}$ and $5 \mathbf{e}$ gave us a hint to perform molecular docking studies to understand the protein-ligand interactions. The docking was performed via the Molegro Virtual Docker 2010.4.1.0 program $^{23}$ for the active site of Staphylococcus epidermidis mevalonate diphosphate decarboxylase (PDB ID: 4DPT) in order to predict the binding mode and support the biological results. ${ }^{24}$

Mevalonate diphosphate decarboxylase (MDD) catalyzed the formation of isopentenyl 5-diphosphate in an ATP-dependent irreversible reaction and was therefore an attractive target for the inhibitor development that could lead to the new antimicrobial agents. ${ }^{24 b}$ In the case of compound $\mathbf{5 b}$, it revealed the MolDock score of $-\mathbf{7 2 . 7 7}$ and formed three interactions, shown as green dotted lines (Fig. 7), which were expressed as hydrogen bonds formed with the oxygen atom of the $\mathrm{C}=\mathrm{O}$ (naphthoquinone) moiety at the position 4 with Arg 144 and Ala 14, with distances of $2.59 \AA$ and $3.19 \AA$, respectively and one hydrogen bond formed between the $-\mathrm{NH}-$ moiety at the position of 3 and Asn 12 of distance $3.35 \AA$.

In the case of the compound $5 \mathbf{e}$, it revealed the MolDock score of -78.46 and formed the main interactions as depicted in Fig. 8, expressed as one hydrogen bond formed with the oxygen atom of the $\mathrm{C}=\mathrm{O}$ (naphthoquinone) moiety at the position 4, and bonds with the oxygen atom of the 2-hydroxypropylthio group with Ala 284 and Ser 141, with distances of $3.14 \AA$ and $2.93 \AA$ A , respectively.

Compound 6 revealed the MolDock score of -56.46 . The supposed Moldock score was found to be positively correlated with the experimental result values, where the antibacterial activities against $S$. epidermidis of the compounds of $5 \mathbf{e}, \mathbf{5 b}$ and 6 decrease from left to right. Interactions with the Arg 144

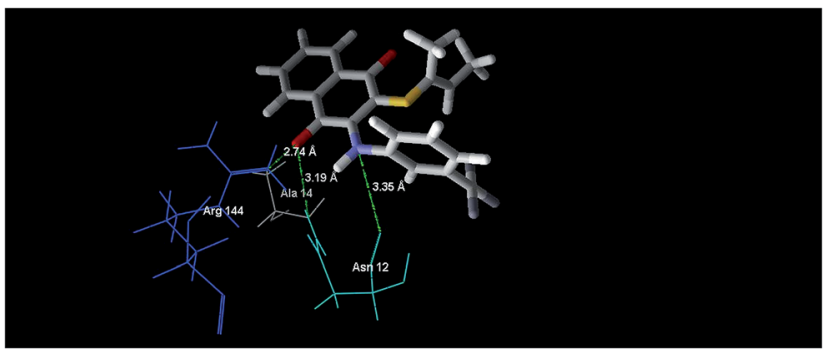

Fig. 7 The binding mode of compound $5 \mathrm{~b}$ in S. epidermidis mevalonate diphosphate decarboxylase [PDB ID: 4DPT].

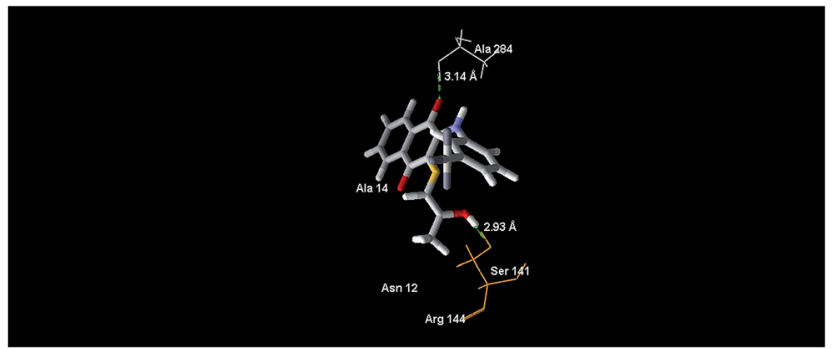

Fig. 8 The binding mode of compound $5 \mathrm{e}$ in S. epidermidis mevalonate diphosphate decarboxylase [PDB ID: 4DPT]. (catalytic site residue, ligand to mevalonate $\mathrm{C} 1$ carboxyl) and Ser 141 (ATP binding motif residue) polar active side chains indicate the binding affinity of the compounds with the protein. This could be further investigated under the topic of MDD inhibitors. ${ }^{25}$

\section{Conclusion}

The sulfanyl 1,4-naphthoquinone derivatives, containing an arylamine with the $-\mathrm{CF}_{3}$ at the different positions $(\mathbf{5 a}-\mathbf{k})$, and 2,3-disulfanyl 1,4-naphthoquinone (6) were synthesized via the nucleophilic substitution of aminonaphthoquinones (3a-c) with 1.1 eq. of aryl- and alkylthiols (4a-d) in $\mathrm{CH}_{2} \mathrm{Cl}_{2}$ in the presence of $\mathrm{Et}_{3} \mathrm{~N}$ (1.1 eq.) as a base at the room temperature. ${ }^{8} \mathrm{All}$ of the newly synthesized compounds (5a-k and 6) were tested for their antimicrobial activities. Based on the testing data for the presented compounds, the in vitro antimicrobial activities were evaluated against the different Gram-positive and Gramnegative bacterial strains in addition to the antifungal activities. The antibacterial profile of the synthesized compounds (5a-k) indicated that compounds (5b-k) had potent antibacterial activities. Among the most promising antibacterial compounds, $\mathbf{5 b}$ and $\mathbf{5 e}$ exhibited better antibacterial activity than clinically prevalent antibacterial drug Cefuroxime against $S$. epidermidis, while $\mathbf{5 f}$ had similar activity. The compounds $\mathbf{5} \mathbf{5 b}$, $\mathbf{5 e}$, and $\mathbf{5 f}$ ) are therefore lead compounds as potent antibacterial agents for further studies. The tested compounds (5b and $\mathbf{5 e}$ ) significantly induced dose-dependent loss of viability in HepG2 cells after $24 \mathrm{~h}$. The $\mathrm{IC}_{50}$ values (5b: $19.54 \mu \mathrm{g} \mathrm{mL}{ }^{-1}$, 5e: $10.18 \mu \mathrm{g}$ $\mathrm{mL}^{-1}$ ) for the compounds were four times higher, compared to the MIC results. These results suggest that the sec-butylthio and 2-hydroxypropylthio moieties with the additional effect of the position of $-\mathrm{CF}_{3}$ are promising leads for the development of antibacterial agents. 5b and 5e were able to inhibit the attachment of bacteria at the MIC or subMIC values and the biofilm formation after 24 hours was approximately $50 \%$, at $1 / 10 \times$ MIC $(p<0.001)$. The molecular docking studies mentioned above further helped in supporting the experimental results. These experimental findings and structures with the additional efforts will pave the way for more potent biologically active derivatives containing the quinone chromophore.

\section{Experimental}

\subsection{Chemistry}

All of the reagents were obtained from the commercial suppliers and were used without further purification unless otherwise noted. Petroleum ether had a boiling range of $40-60{ }^{\circ} \mathrm{C}$. Analytical thin layer chromatography (TLC) plates were purchased from Merck KGaA (silica gel $60 \mathrm{~F}_{254}$ ) based on Merck DC-plates (aluminum based). Visualization of the chromatogram was performed by UV light (254 nm). Column chromatographic separations were carried out using silica gel 60 (Merck, 63-200 $\mu \mathrm{m}$ particle size, 60-230 mesh). ${ }^{1} \mathrm{H}$ NMR and ${ }^{13} \mathrm{C}$ NMR spectra were recorded with the VarianUNITY INOVA spectrometers with $500 \mathrm{MHz}$ frequency for ${ }^{1} \mathrm{H}$ and $125 \mathrm{MHz}$ frequency for ${ }^{13} \mathrm{C}$ NMR in ppm $(\delta) .{ }^{1} \mathrm{H}$ NMR spectra and ${ }^{13} \mathrm{C}$ NMR spectra in 
$\mathrm{CDCl}_{3}$ were referenced to the solvent signals centered at $\delta 7.19$ and $\delta 76.0 \mathrm{ppm}$, respectively. Standard abbreviations indicating multiplicity were used as follows: s (singlet), br s (broad singlet), $\mathrm{d}$ (doublet), t (triplet), and m (multiplet). Coupling constants $J$ were given in Hz. FTIR spectra were recorded as ATR on either a Thermo Scientific Nicolet 6700 spectrometer or Alpha T FTIR spectrometer. Mass spectra were obtained on either a Thermo Finnigan LCQ Advantage MAX MS/MS spectrometer equipped with ESI (electrospray ionization) sources. The purity of the sulfanyl 1,4-naphthoquinone derivatives was obtained by HPLC analysis. HPLC was performed on a Shimadzu/DGU-20A 5 HPLC apparatus fitted with a $25 \mathrm{~cm}$ Chiralpac AD-H chiral column. The melting points (mp) were determined with a Buchi B-540 melting point apparatus, but were uncorrected. The 3arylamino-1,4-naphthoquinone derivatives (3a-c) were prepared via the reaction between the 2,3-dichloro-1,4naphthoquinone (1) and trifluoromethyl substituted aryl amines $(\mathbf{2 a - c})$ according to the literature reported previously and the references cited therein. ${ }^{17,19,26,27}$ All of the synthesized sulfanyl 1,4-naphthoquinone derivatives (5a-k) and side product (6) are new.

4.1.1. General procedure for synthesis of the sulfanyl 1,4naphthoquinone derivatives $(\mathbf{5 a}-\mathbf{k})$. The 3-arylamino-1,4naphthoquinone derivatives $(\mathbf{3 a}-\mathbf{c})$ and thiols in $\mathrm{CH}_{2} \mathrm{Cl}_{2}$ were stirred at room temperature using $\mathrm{Et}_{3} \mathrm{~N}$. The resulting solution was extracted with $100 \mathrm{~mL}$ chloroform, and then washed with water $(4 \times 100 \mathrm{~mL})$ and dried over calcium chloride. The solvent was removed in vacuo. The residue was subjected to column chromatography on silica gel using suitable solvents to give the products.

4.1.1.1. 2-(Sec-butylthio)-3-(4-(trifluoromethyl)phenylamino)naphthalene-1,4-dione (5a). This compound was synthesized from 2-chloro-3-((4-(trifluoromethyl)phenyl)amino)naphthalene1,4-dione (3a) and butane-2-thiol (4a) as a red oil by using the general procedure. Yield: $0.030 \mathrm{~g}, 52 \%$. FTIR (ATR) $\nu\left(\mathrm{cm}^{-1}\right): 3323$ $(-\mathrm{NH}), 3030\left(\mathrm{CH}_{\text {arom }}\right), 2967,2929,2875\left(\mathrm{CH}_{\text {aliphatic }}\right), 1659(\mathrm{C}=\mathrm{O})$. ${ }^{1} \mathrm{H} \mathrm{NMR}\left(500 \mathrm{MHz}, \mathrm{CDCl}_{3}\right) \delta(\mathrm{ppm}): 8.10-8.08 \mathrm{dd}, \mathrm{J}: 7.81,0.98 \mathrm{~Hz}$, $1 \mathrm{H}\left(-\mathrm{CH}_{\text {arom }}\right) ; 8.03-8.01 \mathrm{dd}, \mathrm{J}: 7.81,0.98 \mathrm{~Hz}, 1 \mathrm{H}\left(-\mathrm{CH}_{\text {arom }}\right) ; 7.75$ bs, $1 \mathrm{H}(-\mathrm{NH})$; 7.70-7.66 td, J: 7.33, $1.47 \mathrm{~Hz}, 1 \mathrm{H}\left(-\mathrm{CH}_{\text {arom }}\right) ; 7.63-$ $7.60 \mathrm{td}, \mathrm{J}: 7.81,1.47 \mathrm{~Hz}, 1 \mathrm{H}\left(-\mathrm{CH}_{\text {arom }}\right) ; 7.51-7.49 \mathrm{~d}, \mathrm{~J}: 8.30 \mathrm{~Hz}, 2 \mathrm{H}$ $\left(-\mathrm{CH}_{\text {arom }}\right) ; 6.99-6.97 \mathrm{~d}, \mathrm{~J}: 8.30 \mathrm{~Hz}, 2 \mathrm{H}\left(-\mathrm{CH}_{\text {arom }}\right) ; 3.02-2.98 \mathrm{q}, \mathrm{J}$ : $6.83 \mathrm{~Hz}, 1 \mathrm{H}(-\mathrm{CH}-) ; 1.38-1.28 \mathrm{~m}, 2 \mathrm{H}\left(-\mathrm{CH}_{2}-\right) ; 0.99-0.97 \mathrm{~d}, J: 6.83$ $\mathrm{Hz}, 3 \mathrm{H}\left(-\mathrm{CH}_{3}\right) ; 0.71-0.68 \mathrm{t}, \mathrm{J}: 7.32 \mathrm{~Hz}, 3 \mathrm{H}\left(-\mathrm{CH}_{3}\right) .{ }^{13} \mathrm{C}$ NMR $(125$ $\left.\mathrm{MHz}, C D C l_{3}\right) \delta(\mathrm{ppm}): 180.2,179.1(\mathrm{C}=\mathrm{O}), 143.4,140.5\left(\mathrm{C}_{\mathrm{q}}\right)$, 133.6, 132.1, 126.0, 125.7, $120.5\left(\mathrm{CH}_{\text {arom }}\right), 132.2,129.7,124.7\left(\mathrm{C}_{\mathrm{q}}\right)$, 43.3 (-CH-); $28.8\left(-\mathrm{CH}_{2}-\right)$; 19.4, $10.1\left(-\mathrm{CH}_{3}\right)$. MS (ESI-) $m / z(\%)$ : $402\left(100,[\mathrm{M}-3 \mathrm{H}]^{+}\right), 403\left(22,[\mathrm{M}-2 \mathrm{H}]^{+}\right)$. Anal. calcd for $\mathrm{C}_{21} \mathrm{H}_{18} \mathrm{~F}_{3} \mathrm{NO}_{2} \mathrm{~S}$ (405.43).

Additionally, 6 was also obtained from 2-chloro-3-((4(trifluoromethyl)phenyl)amino)naphthalene-1,4-dione (3a) and butane-2-thiol (4a) by using the general procedure.

4.1.1.1.1 2,3-Bis(sec-butylthio)naphthalene-1,4-dione (6). Red oil, yield: $0.035 \mathrm{~g}$, 37\%. FTIR (ATR) $\nu\left(\mathrm{cm}^{-1}\right): 2967,2925,2875$ $\left(-\mathrm{CH}_{\text {aliphatic }}\right), 1661(\mathrm{C}=\mathrm{O}) .{ }^{1} \mathrm{H}$ NMR $\left(500 \mathrm{MHz}, C D C l_{3}\right) \delta(\mathrm{ppm})$ : 7.99-7.98 dd, J: 5.37, $2.93 \mathrm{~Hz}, 2 \mathrm{H}$ (- $\left.\mathrm{CH}_{\text {arom }}\right)$; 7.62-7.61 dd, J: $5.86,2.93 \mathrm{~Hz}, 2 \mathrm{H}\left(-\mathrm{CH}_{\text {arom }}\right) ; 4.04-4.00 \mathrm{q}, \mathrm{J}: 6.83 \mathrm{~Hz}, 2 \mathrm{H}(-\mathrm{CH}-)$;
1.61-1.48 m, 4H (- $\left.\mathrm{CH}_{2}-\right) ; 1.24-1.22 \mathrm{dd}, \mathrm{J}: 6.84,2.93 \mathrm{~Hz}, 6 \mathrm{H}$ $\left(-\mathrm{CH}_{3}\right) ; 0.96-0.93 \mathrm{td}, \mathrm{J}: 7.32,2.44 \mathrm{~Hz}, 6 \mathrm{H},\left(-\mathrm{CH}_{3}\right) .{ }^{13} \mathrm{C} \mathrm{NMR}(125$ $\left.\mathrm{MHz}, \mathrm{CDCl}_{3}\right) \delta(\mathrm{ppm}): 178.3(-\mathrm{C}=\mathrm{O}) ; 148.1\left(\mathrm{C}_{\mathrm{q}}\right) ; 132.4,125.9$ $\left(-\mathrm{CH}_{\text {arom }}\right) ; 132.1\left(\mathrm{C}_{\mathrm{q}}\right) ; 44.5(-\mathrm{CH}-) ; 29.8\left(-\mathrm{CH}_{2}-\right) ; 20.2,20.1,10.4$, $10.3\left(-\mathrm{CH}_{3}\right) . \mathrm{MS}(\mathrm{ESI}+) \mathrm{m} / z(\%): 334\left(100,[\mathrm{M}]^{+}\right), 335$ (71, [M + $\mathrm{H}]^{+}$). Anal. calcd for $\mathrm{C}_{18} \mathrm{H}_{22} \mathrm{O}_{2} \mathrm{~S}_{2}$ (334.50).

4.1.1.2. 2-(Sec-butylthio)-3-(3-(trifluoromethyl)phenylamino)naphthalene-1,4-dione (5b). This compound was synthesized from 2-chloro-3-((3-(trifluoromethyl)phenyl)amino)naphthalene1,4-dione (3b) and butane-2-thiol (4a) as a red powder by using the general procedure. Yield: $0.045 \mathrm{~g}$, mp: $109-110{ }^{\circ} \mathrm{C}, 39 \%$. FTIR $($ ATR $) \nu\left(\mathrm{cm}^{-1}\right): 3275$ (-NH), $3076\left(-\mathrm{CH}_{\text {arom }}\right), 2967,2929$ $\left(-\mathrm{CH}_{\text {aliphatic }}\right), 1662(-\mathrm{C}=\mathrm{O}) .{ }^{1} \mathrm{H}$ NMR $\left(500 \mathrm{MHz}, C D C l_{3}\right) \delta(\mathrm{ppm})$ : 8.09-8.08 d, J: $7.81 \mathrm{~Hz}, 1 \mathrm{H}\left(-\mathrm{CH}_{\text {arom }}\right) ; 8.01-8.00 \mathrm{~d}, \mathrm{~J}: 7.81 \mathrm{~Hz}, 1 \mathrm{H}$ $\left(-\mathrm{CH}_{\text {arom }}\right) ; 7.78 \mathrm{~s}, 1 \mathrm{H}(-\mathrm{NH}) ; 7.69-7.65 \mathrm{td}, \mathrm{J}: 7.32,0.97 \mathrm{~Hz}, 1 \mathrm{H}$ $\left(-\mathrm{CH}_{\text {arom }}\right)$; $7.62-7.59 \mathrm{t}, \mathrm{J}$ : $7.32 \mathrm{~Hz}, 2 \mathrm{H},\left(-\mathrm{CH}_{\text {arom }}\right)$; 7.38-7.35 t, J: $7.81 \mathrm{~Hz}, 1 \mathrm{H}\left(-\mathrm{CH}_{\text {arom }}\right) ; 7.32-7.30 \mathrm{~d}, \mathrm{~J}: 7.81 \mathrm{~Hz}, 1 \mathrm{H}\left(-\mathrm{CH}_{\text {arom }}\right) ; 7.09-$ $7.08 \mathrm{~d}, \mathrm{~J}: 7.81 \mathrm{~Hz}, 1 \mathrm{H},\left(-\mathrm{CH}_{\text {arom }}\right) ; 2.98-2.93 \mathrm{~m}, 1 \mathrm{H}(-\mathrm{CH}-) ; 1.36-$ $1.23 \mathrm{~m}, 2 \mathrm{H}\left(-\mathrm{CH}_{2}-\right) ; 0.97-0.95 \mathrm{~d}, \mathrm{~J}: 6.83 \mathrm{~Hz}, 3 \mathrm{H}\left(-\mathrm{CH}_{3}\right) ; 0.69-0.66$ t, J: $7.32 \mathrm{~Hz}, 3 \mathrm{H}\left(-\mathrm{CH}_{3}\right) .{ }^{13} \mathrm{C}$ NMR $\left(125 \mathrm{MHz}, C C_{3}\right) \delta(\mathrm{ppm})$ : 180.2, $179.1(-\mathrm{C}=\mathrm{O})$; 143.7, 137.8, 132.3, 129.7, 127.8, 124.4, 119.9, 118.9, $118.1\left(\mathrm{C}_{\mathrm{q}}\right)$; 133.6, 132.0, 126.0, $125.7\left(-\mathrm{CH}_{\text {arom }}\right) ; 43.2$ $(-\mathrm{CH}-) ; 28.7\left(-\mathrm{CH}_{2}-\right)$; 19.3, $10.1\left(-\mathrm{CH}_{3}\right) . \mathrm{MS}(\mathrm{ESI}+) \mathrm{m} / \mathrm{z}(\%): 406$ $\left(100,[\mathrm{M}+\mathrm{H}]^{+}\right)$. Anal. calcd for $\mathrm{C}_{21} \mathrm{H}_{18} \mathrm{~F}_{3} \mathrm{NO}_{2} \mathrm{~S}(405.43)$.

4.1.1.3. 2-(Sec-butylthio)-3-((2-(trifluoromethyl)phenyl)amino)naphthalene-1,4-dione $(\mathbf{5 c})$. This compound was synthesized from 2-chloro-3-((2-(trifluoromethyl)phenyl)amino)naphthalene1,4-dione (3c) and butane-2-thiol (4a) as a red oil by using the general procedure. Yield: $0.039 \mathrm{~g}, 70 \%$. FTIR (ATR) $\nu\left(\mathrm{cm}^{-1}\right): 3328$ $(-\mathrm{NH}), 3072\left(-\mathrm{CH}_{\text {arom }}\right), 2963,2922,2872\left(-\mathrm{CH}_{\text {aliphatic }}\right), 1664(-\mathrm{C}=$ O). ${ }^{1} \mathrm{H}$ NMR (500 MHz, $\left.C D C l_{3}\right) \delta$ (ppm): 8.08-8.07 dd, J: 7.32, 1.46 $\mathrm{Hz}, 1 \mathrm{H}\left(-\mathrm{CH}_{\text {arom }}\right) ; 8.00-7.98 \mathrm{dd}, \mathrm{J}: 7.32,1.46 \mathrm{~Hz}, 1 \mathrm{H}\left(-\mathrm{CH}_{\text {arom }}\right)$; $7.91 \mathrm{~s}, 1 \mathrm{H}(-\mathrm{NH}) ; 7.68-7.65 \mathrm{td}, \mathrm{J}: 7.81,0.98 \mathrm{~Hz}, 1 \mathrm{H}\left(-\mathrm{CH}_{\text {arom }}\right)$; $7.61-7.58 \mathrm{~m}, 2 \mathrm{H},\left(-\mathrm{CH}_{\text {arom }}\right) ; 7.43-7.40 \mathrm{t}, \mathrm{J}: 7.81 \mathrm{~Hz}, 1 \mathrm{H}\left(-\mathrm{CH}_{\text {arom }}\right)$; 7.19-7.16 t, J: $7.81 \mathrm{~Hz}, 1 \mathrm{H}\left(-\mathrm{CH}_{\text {arom }}\right) ; 6.90-6.88 \mathrm{~d}, \mathrm{~J}: 8.30 \mathrm{~Hz}, 1 \mathrm{H}$, $\left(-\mathrm{CH}_{\text {arom }}\right) ; 3.07-3.02 \mathrm{~m}, 1 \mathrm{H}(-\mathrm{CH}-) ; 1.42-1.26 \mathrm{~m}, 2 \mathrm{H}\left(-\mathrm{CH}_{2}-\right)$; 0.99-0.98 d, J: $6.34 \mathrm{~Hz}, 3 \mathrm{H}\left(-\mathrm{CH}_{3}\right) ; 0.73-0.70 \mathrm{t}, \mathrm{J}: 7.32 \mathrm{~Hz}, 3 \mathrm{H}$ $\left(-\mathrm{CH}_{3}\right) \cdot{ }^{13} \mathrm{C} \mathrm{NMR}\left(125 \mathrm{MHz}, \mathrm{CDCl}_{3}\right) \delta(\mathrm{ppm}): 180.1,178.8(-\mathrm{C}=\mathrm{O})$; 144.9, 132.2 , 130.8, 129.8, 125.3, $118.9\left(\mathrm{C}_{\mathrm{q}}\right)$; 133.5, 125.9, 125.7, 124.0, $123.4\left(-\mathrm{CH}_{\text {arom }}\right) ; 43.3(-\mathrm{CH}-) ; 28.9\left(-\mathrm{CH}_{2}-\right) ; 19.3,10.0$ $\left(-\mathrm{CH}_{3}\right) . \mathrm{MS}(\mathrm{ESI}+) \mathrm{m} / \mathrm{z}(\%): 406\left(100,[\mathrm{M}+\mathrm{H}]^{+}\right)$. Anal. calcd for $\mathrm{C}_{21} \mathrm{H}_{18} \mathrm{~F}_{3} \mathrm{NO}_{2} \mathrm{~S}$ (405.43).

4.1.1.4. 2-(2-Hydroxypropylthio)-3-(4-(trifluoromethyl)phenylamino)naphthalene-1,4-dione (5d). This compound was synthesized from 2-chloro-3-((4-(trifluoromethyl)phenyl)amino) naphthalene-1,4-dione (3a) and 3-mercaptobutan-2-ol (4b) as an orange powder by using the general procedure. Yield: $0.085 \mathrm{~g}, \mathrm{mp}: 139-140{ }^{\circ} \mathrm{C}, 73 \%$. FTIR (ATR) $\nu\left(\mathrm{cm}^{-1}\right): 3419$ $(-\mathrm{OH}), 3336(-\mathrm{NH}), 3030\left(-\mathrm{CH}_{\text {arom }}\right), 2978,2961,2929$ $\left(-\mathrm{CH}_{\text {aliphatic }}\right), 1669(-\mathrm{C}=\mathrm{O}) .{ }^{1} \mathrm{H}$ NMR $\left(500 \mathrm{MHz}, \mathrm{CDCl}_{3}\right)$ $\delta(\mathrm{ppm}): 8.10-8.08 \mathrm{dd}, J: 7.81,1.46 \mathrm{~Hz}, 1 \mathrm{H}\left(-\mathrm{CH}_{\text {arom }}\right) ; 8.03-$ $8.01 \mathrm{dd}, \mathrm{J}: 7.32,0.98 \mathrm{~Hz}, 1 \mathrm{H}\left(-\mathrm{CH}_{\text {arom }}\right) ; 7.86 \mathrm{~s}, 1 \mathrm{H}(-\mathrm{NH}) ; 7.71-$ $7.68 \mathrm{td}, \mathrm{J}: 7.32,1.47 \mathrm{~Hz}, 1 \mathrm{H}\left(-\mathrm{CH}_{\text {arom }}\right) ; 7.64-7.61 \mathrm{td}, \mathrm{J}: 7.32$, $1.46 \mathrm{~Hz}, 1 \mathrm{H}\left(-\mathrm{CH}_{\text {arom }}\right) ; 7.53-7.51 \mathrm{~d}, \mathrm{~J}: 8.78 \mathrm{~Hz}, 2 \mathrm{H}\left(-\mathrm{CH}_{\text {arom }}\right)$; $7.05-7.03 \mathrm{~d}, \mathrm{~J}: 8.79 \mathrm{~Hz}, 2 \mathrm{H}\left(-\mathrm{CH}_{\text {arom }}\right) ; 3.64-3.60 \mathrm{~m}, 1 \mathrm{H}$ (-CH-); $2.77-2.73 \mathrm{dd}, J: 13.18,2.93 \mathrm{~Hz}, 1 \mathrm{H}\left(-\mathrm{CH}_{2}-\right) ; 2.48-2.43 \mathrm{dd}, J$ : 13.66, 8.78 Hz, $1 \mathrm{H}\left(-\mathrm{CH}_{2}-\right)$; $1.06-1.05 \mathrm{~d}, \mathrm{~J}: 6.34 \mathrm{~Hz}, 3 \mathrm{H}\left(-\mathrm{CH}_{3}\right)$. 
${ }^{13} \mathrm{C}$ NMR $\left(125 \mathrm{MHz}, C D C l_{3}\right) \delta(\mathrm{ppm}): 181.4,180.3(-\mathrm{C}=\mathrm{O})$; $135.1,133.5,127.4,127.1$ (-CH arom $) ; 146.2,142.1,133.5$, $130.8,126.2,122.5\left(\mathrm{C}_{\mathrm{q}}\right) ; 66.5(-\mathrm{CH}-) ; 43.6\left(-\mathrm{CH}_{2}-\right) ; 22.1$ $\left(-\mathrm{CH}_{3}\right)$. MS (ESI+) $m / z(\%): 429\left(100,[\mathrm{M}+\mathrm{Na}]^{+}\right), 407\left(52,[\mathrm{M}]^{+}\right)$. Anal. calcd for $\mathrm{C}_{20} \mathrm{H}_{16} \mathrm{~F}_{3} \mathrm{NO}_{3} \mathrm{~S}$ (407.41).

4.1.1.5. 2-(2-Hydroxypropylthio)-3-(3-(trifluoromethyl)phenylamino)naphthalene-1,4-dione (5e). This compound was synthesized from 2-chloro-3-((3-(trifluoromethyl)phenyl)amino) naphthalene-1,4-dione (3b) and 3-mercaptobutan-2-ol (4b) as a red oil by using the general procedure. Yield: $0.076 \mathrm{~g}$, 65\%. FTIR (ATR) $\nu\left(\mathrm{cm}^{-1}\right): 3433(-\mathrm{OH}), 3346(-\mathrm{NH}), 3050$ $\left(-\mathrm{CH}_{\text {arom }}\right), 2980,2930$ (-CH $\left.\mathrm{CH}_{\text {aliphatic }}\right), 1664(-\mathrm{C}=\mathrm{O}) .{ }^{1} \mathrm{H}$ NMR $\left(500 \mathrm{MHz}, C D C l_{3}\right) \delta(\mathrm{ppm}): 8.09-8.07 \mathrm{~d}, J: 7.81 \mathrm{~Hz}, 1 \mathrm{H}$ $\left(-\mathrm{CH}_{\text {arom }}\right) ; 8.01-7.99 \mathrm{~d}, \mathrm{~J}: 7.32 \mathrm{~Hz}, 1 \mathrm{H}\left(-\mathrm{CH}_{\text {arom }}\right) ; 7.91 \mathrm{~s}, 1 \mathrm{H}$ $(-\mathrm{NH}) ; 7.70-7.66 \mathrm{td}, \mathrm{J}: 7.81,1.46 \mathrm{~Hz}, 1 \mathrm{H}\left(-\mathrm{CH}_{\text {arom }}\right) ; 7.62-7.59$ td, J: 7.32, $1.47 \mathrm{~Hz}, 1 \mathrm{H}\left(-\mathrm{CH}_{\text {arom }}\right) ; 7.41-7.35 \mathrm{t}, J: 7.81 \mathrm{~Hz}, 1 \mathrm{H}$ $\left(-\mathrm{CH}_{\text {arom }}\right) ; 7.37-7.35 \mathrm{t}, \mathrm{J}: 7.81 \mathrm{~Hz}, 1 \mathrm{H}\left(-\mathrm{CH}_{\text {arom }}\right) ; 7.25 \mathrm{~s}, 1 \mathrm{H}$ $\left(-\mathrm{CH}_{\text {arom }}\right) ; 7.16-7.15 \mathrm{~d}, \mathrm{~J}: 7.32 \mathrm{~Hz}, 1 \mathrm{H}\left(-\mathrm{CH}_{\text {arom }}\right) ; 3.62-3.58 \mathrm{~m}$, $1 \mathrm{H}(-\mathrm{CH}-)$; 2.71-2.68 dd, J: 13.67, $3.42 \mathrm{~Hz}, 1 \mathrm{H}\left(-\mathrm{CH}_{2}-\right) ; 2.43-$ $2.39 \mathrm{dd}, \mathrm{J}: 13.67,8.79 \mathrm{~Hz}, 1 \mathrm{H}\left(-\mathrm{CH}_{2}-\right)$; $1.05-1.03 \mathrm{~d}, \mathrm{~J}: 6.35 \mathrm{~Hz}$, $3 \mathrm{H}\left(-\mathrm{CH}_{3}\right) .{ }^{13} \mathrm{C}$ NMR $\left(125 \mathrm{MHz}, C D C l_{3}\right) \delta(\mathrm{ppm}): 181.5,180.4$ $(-\mathrm{C}=\mathrm{O}) ; 146.7,139.6,133.5,130.7,129.4,126.4,122.0,120.1$, $117.4\left(\mathrm{C}_{\mathrm{q}}\right)$; 135.1, 133.3, 127.4, $127.1\left(-\mathrm{CH}_{\text {arom }}\right)$; $66.4(-\mathrm{CH}-)$; $43.8\left(-\mathrm{CH}_{2}-\right) ; 22.1\left(-\mathrm{CH}_{3}\right)$. MS (ESI-) $\mathrm{m} / z(\%): 407\left(16,[\mathrm{M}]^{+}\right)$, $406\left(35,[\mathrm{M}-\mathrm{H}]^{+}\right), 405\left(100,[\mathrm{M}-2 \mathrm{H}]^{+}\right)$. Anal. calcd for $\mathrm{C}_{20} \mathrm{H}_{16} \mathrm{~F}_{3} \mathrm{NO}_{3} \mathrm{~S}$ (407.41).

4.1.1.6. 2-((2-Hydroxypropyl)thio)-3-((2-(trifluoromethyl)phenyl)amino)naphthalene-1,4-dione (5f). This compound was synthesized from 2-chloro-3-((2-(trifluoromethyl)phenyl)amino)naphthalene1,4-dione (3c) and 3-mercaptobutan-2-ol (4b) as a red powder by using the general procedure. Yield: $0.059 \mathrm{~g}$, mp: $85-87{ }^{\circ} \mathrm{C}, 66 \%$. FTIR (ATR) $\nu\left(\mathrm{cm}^{-1}\right): 3423(-\mathrm{OH}), 3328(-\mathrm{NH}), 3075\left(-\mathrm{CH}_{\text {arom}}\right)$, 2966, 2919 (-CH $\left.\mathrm{CH}_{\text {aliphatic }}\right), 1667(-\mathrm{C}=\mathrm{O}) .{ }^{1} \mathrm{H} \mathrm{NMR}\left(500 \mathrm{MHz}, C C_{3}\right)$ $\delta$ (ppm): 8.09-8.07 dd, J: 7.32, $0.98 \mathrm{~Hz}, 1 \mathrm{H}\left(-\mathrm{CH}_{\text {arom }}\right) ; 8.01-7.99 \mathrm{dd}$, J: $7.81,0.97 \mathrm{~Hz}, 1 \mathrm{H}\left(-\mathrm{CH}_{\text {arom }}\right) ; 7.93 \mathrm{~s}, 1 \mathrm{H}(-\mathrm{NH}) ; 7.70-7.66 \mathrm{td}, J$ : $7.81,1.46 \mathrm{~Hz}, 1 \mathrm{H}\left(-\mathrm{CH}_{\text {arom }}\right) ; 7.62-7.60 \mathrm{~m}, 2 \mathrm{H}\left(-\mathrm{CH}_{\text {arom }}\right) ; 7.47-7.44$ t, J: $7.80 \mathrm{~Hz}, 1 \mathrm{H}\left(-\mathrm{CH}_{\text {arom }}\right) ; 7.26-7.23 \mathrm{t}, \mathrm{J}: 7.80 \mathrm{~Hz}, 1 \mathrm{H}\left(-\mathrm{CH}_{\text {arom }}\right)$; 7.00-6.99 d, J: $7.80 \mathrm{~Hz}, 1 \mathrm{H}\left(-\mathrm{CH}_{\text {arom }}\right) ; 3.62-3.54 \mathrm{~m}, 1 \mathrm{H}(-\mathrm{CH}-)$; $2.96 \mathrm{~s}, 1 \mathrm{H}(-\mathrm{OH}) ; 2.78-2.75 \mathrm{dd}, \mathrm{J}: 13.67,2.96 \mathrm{~Hz}, 1 \mathrm{H}\left(-\mathrm{CH}_{2}-\right) ; 2.42-$ $2.38 \mathrm{dd}, \mathrm{J}: 13.67,8.79 \mathrm{~Hz}, 1 \mathrm{H}\left(-\mathrm{CH}_{2}-\right) ; 1.04-1.03 \mathrm{~d}, \mathrm{~J}: 6.35 \mathrm{~Hz}, 3 \mathrm{H}$ $\left(-\mathrm{CH}_{3}\right) \cdot{ }^{13} \mathrm{C} \mathrm{NMR}\left(125 \mathrm{MHz}, \mathrm{CDCl}_{3}\right) \delta(\mathrm{ppm}): 180.3,178.8(-\mathrm{C}=\mathrm{O})$; 146.2, 132.2, 131.1, 129.5, $125.6\left(\mathrm{C}_{\mathrm{q}}\right)$; 133.8, 132.1, 126.2, 125.9, 124.9, $124.4\left(-\mathrm{CH}_{\text {arom }}\right) ; 65.0(-\mathrm{CH}-) ; 42.7\left(-\mathrm{CH}_{2}-\right) ; 20.7\left(-\mathrm{CH}_{3}\right) . \mathrm{MS}$ $(\mathrm{ESI}+) \mathrm{m} / z(\%): 408\left(100,[\mathrm{M}+\mathrm{H}]^{+}\right), 430\left(54,[\mathrm{M}+\mathrm{Na}]^{+}\right)$. Anal. calcd for $\mathrm{C}_{20} \mathrm{H}_{16} \mathrm{~F}_{3} \mathrm{NO}_{3} \mathrm{~S}$ (407.41).

4.1.1.7. 2-(Furan-2-ylmethylthio)-3-(4-(trifluoromethyl)phenylamino)naphthalene-1,4-dione (5g). This compound was synthesized from 2-chloro-3-((4-(trifluoromethyl)phenyl)amino) naphthalene-1,4-dione (3a) and furan-2-ylmethanethiol (4c) as a red powder by using the general procedure. Yield: $0.037 \mathrm{~g}, \mathrm{mp}$ : 91-92 ${ }^{\circ} \mathrm{C}, 30 \%$. FTIR (ATR) $\nu\left(\mathrm{cm}^{-1}\right): 3334(-\mathrm{NH}), 3104(-\mathrm{C}-$ O- $\left.{ }_{\text {ether }}\right), 2964,2918,2851$ (- $\left.\mathrm{CH}_{\text {aliphatic }}\right), 1659(-\mathrm{C}=\mathrm{O}) .{ }^{1} \mathrm{H}$ NMR (500 MHz, $\left.\mathrm{CDCl}_{3}\right) \delta(\mathrm{ppm}): 8.10-8.08 \mathrm{dd}, \mathrm{J}: 7.81,1.46 \mathrm{~Hz}, 1 \mathrm{H}$ $\left(-\mathrm{CH}_{\text {arom }}\right) ; 7.99-7.97 \mathrm{dd}, \mathrm{J}: 7.81,1.46 \mathrm{~Hz}, 1 \mathrm{H}\left(-\mathrm{CH}_{\text {arom }}\right) ; 7.70-$ $7.67 \mathrm{td}, J: 7.32,1.46 \mathrm{~Hz}, 1 \mathrm{H}\left(-\mathrm{CH}_{\text {arom }}\right) ; 7.66 \mathrm{bs}, 1 \mathrm{H}(-\mathrm{NH}) ; 7.62-$ $7.59 \mathrm{td}, \mathrm{J}: 7.81,1.47 \mathrm{~Hz}, 1 \mathrm{H}\left(-\mathrm{CH}_{\text {arom }}\right) ; 7.48-7.47 \mathrm{~d}, \mathrm{~J}: 8.30 \mathrm{~Hz}, 2 \mathrm{H}$ $\left(-\mathrm{CH}_{\text {arom }}\right) ; 7.12-7.11 \mathrm{t}, \mathrm{J}: 0.98 \mathrm{~Hz}, 1 \mathrm{H},\left(-\mathrm{CH}_{\text {arom }}\right)$; 6.93-6.91 d, J:
$8.29 \mathrm{~Hz}, 2 \mathrm{H}\left(-\mathrm{CH}_{\text {arom }}\right) ; 6.09-6.08 \mathrm{dd}, J: 2.93,1.95 \mathrm{~Hz}, 1 \mathrm{H}$ $\left(-\mathrm{CH}_{\text {arom }}\right) ; 5.88-5.87 \mathrm{~d}, \mathrm{~J}: 3.42 \mathrm{~Hz}, 1 \mathrm{H}\left(-\mathrm{CH}_{\text {arom }}\right) ; 3.91 \mathrm{~s}, 2 \mathrm{H}$ $\left(-\mathrm{CH}_{2}-\right) \cdot{ }^{13} \mathrm{C} \mathrm{NMR}\left(125 \mathrm{MHz}, C D C l_{3}\right) \delta(\mathrm{ppm}): 179.7,178.9(-\mathrm{C}=$ O); 149.7, 144.8, 141.2, $140.9\left(\mathrm{C}_{\mathrm{q}}\right)$; 133.7, 132.3, 132.0, 129.6, 125.9, 125.8, 121.0 (- $\left.\mathrm{CH}_{\text {arom }}\right)$; 124.8, 117.4, 109.5, $107.2\left(\mathrm{C}_{\mathrm{q}}\right)$; $29.4\left(-\mathrm{CH}_{2}-\right)$. MS (ESI+) $m / z(\%): 452\left(27,[\mathrm{M}+\mathrm{Na}]^{+}\right), 451(100,[\mathrm{M}$ $+\mathrm{Na}-1]^{+}$). Anal. calcd for $\mathrm{C}_{22} \mathrm{H}_{14} \mathrm{~F}_{3} \mathrm{NO}_{3} \mathrm{~S}$ (429.41).

4.1.1.8. 2-(Furan-2-ylmethylthio)-3-(3-(trifluoromethyl)phenylamino)naphthalene-1,4-dione (5h). This compound was synthesized from 2-chloro-3-((3-(trifluoromethyl)phenyl)amino) naphthalene-1,4-dione (3b) and furan-2-ylmethanethiol (4c) as a red oil by using the general procedure. Yield: $0.08 \mathrm{~g}, 66 \%$. FTIR (ATR) $\nu\left(\mathrm{cm}^{-1}\right): 3308(-\mathrm{NH}), 3072\left(-\mathrm{C}-\mathrm{O}_{\text {ether }}\right), 2928$ $\left(-\mathrm{CH}_{\text {aliphatic }}\right), 1668(-\mathrm{C}=\mathrm{O}) .{ }^{1} \mathrm{H} \mathrm{NMR}\left(500 \mathrm{MHz}, C D C l_{3}\right) \delta(\mathrm{ppm})$ : 8.11-8.10 d, J: $7.81 \mathrm{~Hz}, 1 \mathrm{H}\left(-\mathrm{CH}_{\text {arom }}\right) ; 7.99-7.97 \mathrm{~d}, \mathrm{~J}: 7.80 \mathrm{~Hz}, 1 \mathrm{H}$ $\left(-\mathrm{CH}_{\text {arom }}\right) ; 7.71-7.67 \mathrm{td}, \mathrm{J}: 7.81,1.46 \mathrm{~Hz}, 1 \mathrm{H}\left(-\mathrm{CH}_{\text {arom }}\right) ; 7.66 \mathrm{~s}, 1 \mathrm{H}$ $(-\mathrm{NH}) ; 7.62-7.59 \mathrm{td}, \mathrm{J}: 7.81,1.46 \mathrm{~Hz}, 1 \mathrm{H}\left(-\mathrm{CH}_{\text {arom }}\right) ; 7.35-7.34 \mathrm{~m}$, $2 \mathrm{H}\left(-\mathrm{CH}_{\text {arom }}\right) ; 7.13-7.12 \mathrm{~m}, 2 \mathrm{H}\left(-\mathrm{CH}_{\text {arom }}\right) ; 7.03-7.01 \mathrm{~m}, 1 \mathrm{H}$ $\left(-\mathrm{CH}_{\text {arom }}\right) ; 6.10-6.09 \mathrm{dd}, \mathrm{J}: 3.41,1.47 \mathrm{~Hz}, 1 \mathrm{H}\left(-\mathrm{CH}_{\text {arom }}\right)$; 5.87$5.86 \mathrm{~d}, \mathrm{~J}: 3.41 \mathrm{~Hz}, 1 \mathrm{H}\left(-\mathrm{CH}_{\text {arom }}\right) ; 3.88 \mathrm{~s}, 2 \mathrm{H}\left(-\mathrm{CH}_{2}-\right) .{ }^{13} \mathrm{C} \mathrm{NMR}$ $\left(125 \mathrm{MHz}, C \mathrm{Cl}_{3}\right) \delta(\mathrm{ppm}):$ 179.6, $179.0(-\mathrm{C}=\mathrm{O}) ; 149.8,145.7$, 141.2, 138.5, 132.4, 129.6, 128.1, 125.0, 120.5, 118.7, $115.9\left(\mathrm{C}_{\mathrm{q}}\right)$; 133.7, 131.9, 126.0, 125.8, 109.5, $107.2\left(-\mathrm{CH}_{\text {arom }}\right)$; $29.6\left(-\mathrm{CH}_{2}-\right)$. MS (ESI-) $m / z(\%): 428\left(100,[\mathrm{M}-\mathrm{H}]^{+}\right)$. Anal. calcd for $\mathrm{C}_{22} \mathrm{H}_{14} \mathrm{~F}_{3} \mathrm{NO}_{3} \mathrm{~S}$ (429.41).

4.1.1.9. 2-((Furan-2-ylmethyl)thio)-3-((2-(trifluoromethyl)phenyl)amino)naphthalene-1,4-dione (5i). This compound was synthesized from 2-chloro-3-((2-(trifluoromethyl)phenyl)amino)naphthalene1,4-dione (3c) and furan-2-ylmethanethiol (4c) as a red oil by using the general procedure. Yield: $0.07 \mathrm{~g}, 85 \%$. FTIR (ATR) $\nu$ $\left(\mathrm{cm}^{-1}\right): 3294(-\mathrm{NH}), 2922\left(-\mathrm{CH}_{\text {aliphatic }}\right), 1676(-\mathrm{C}=\mathrm{O}) .{ }^{1} \mathrm{H}$ NMR $(500$ $\left.\mathrm{MHz}, \mathrm{CDCl}_{3}\right) \delta$ (ppm): 8.09-8.07 dd, J: 7.81, $0.98 \mathrm{~Hz}, 1 \mathrm{H}\left(-\mathrm{CH}_{\text {arom }}\right)$; 7.97-7.95 dd, J: 7.81, $0.98 \mathrm{~Hz}, 1 \mathrm{H}\left(-\mathrm{CH}_{\text {arom }}\right) ; 7.75 \mathrm{~s}, 1 \mathrm{H}(-\mathrm{NH}) ; 7.68-$ $7.65 \mathrm{td}, \mathrm{J}: 7.32,1.46 \mathrm{~Hz}, 1 \mathrm{H}\left(-\mathrm{CH}_{\text {arom }}\right) ; 7.60-7.56 \mathrm{~m}, 2 \mathrm{H}\left(-\mathrm{CH}_{\text {arom }}\right)$; 7.39-7.36 t, J: $7.80 \mathrm{~Hz}, 1 \mathrm{H}\left(-\mathrm{CH}_{\text {arom }}\right) ; 7.21-7.17 \mathrm{q}, J: 7.32 \mathrm{~Hz}, 1 \mathrm{H}$ $\left(-\mathrm{CH}_{\text {arom }}\right) ; 7.12-7.10 \mathrm{~d}, \mathrm{~J}: 2.44 \mathrm{~Hz}, 1 \mathrm{H}\left(-\mathrm{CH}_{\text {arom }}\right) ; 6.82-6.80 \mathrm{~d}, \mathrm{~J}: 7.81$ $\mathrm{Hz}, 1 \mathrm{H}\left(-\mathrm{CH}_{\text {arom }}\right) ; 6.07-6.06 \mathrm{dd}, \mathrm{J}: 3.44,1.96 \mathrm{~Hz}, 1 \mathrm{H}\left(-\mathrm{CH}_{\text {arom }}\right)$; $5.86-5.85 \mathrm{~d}, \mathrm{~J}: 3.90 \mathrm{~Hz}, 1 \mathrm{H}\left(-\mathrm{CH}_{\text {arom }}\right) ; 3.91 \mathrm{~s}, 2 \mathrm{H}\left(-\mathrm{CH}_{2}-\right) .{ }^{13} \mathrm{C} \mathrm{NMR}$ $\left(125 \mathrm{MHz}, \mathrm{CDCl}_{3}\right) \delta(\mathrm{ppm}): 179.6,178.7(-\mathrm{C}=\mathrm{O}) ; 149.7,145.9$, 141.2, 132.4, 130.9, 129.5, 125.5, 116.6, $116.1\left(\mathrm{C}_{\mathrm{q}}\right)$; 133.7, 131.9, 131.8, 125.9, 125.7, 124.5, $124.0\left(-\mathrm{CH}_{\text {arom }}\right) ; 29.4\left(-\mathrm{CH}_{2}-\right) . \mathrm{MS}(\mathrm{ESI}+)$ $m / z(\%): 452\left(100,[\mathrm{M}+\mathrm{Na}]^{+}\right), 430\left(22,[\mathrm{M}+\mathrm{H}]^{+}\right)$. Anal. calcd for $\mathrm{C}_{22} \mathrm{H}_{14} \mathrm{~F}_{3} \mathrm{NO}_{3} \mathrm{~S}$ (429.41).

4.1.1.10. 2-(Phenethylthio)-3-(4-(trifluoromethyl)phenylamino)naphthalene-1,4-dione (5j). This compound was synthesized from 2-chloro-3-((4-(trifluoromethyl)phenyl)amino)naphthalene-1,4dione (3a) and 2-phenylethanethiol (4d) as a red powder by using the general procedure. Yield: $0.074 \mathrm{~g}$, mp: $85-87^{\circ} \mathrm{C}, 57 \%$. FTIR (ATR) $\nu\left(\mathrm{cm}^{-1}\right): 3321(-\mathrm{NH}), 3272,3060,3025\left(-\mathrm{CH}_{\text {arom }}\right)$; $2930\left(-\mathrm{CH}_{\text {aliphatic }}\right), 1662(-\mathrm{C}=\mathrm{O}) .{ }^{1} \mathrm{H} \mathrm{NMR}\left(500 \mathrm{MHz}, C D C l_{3}\right)$ $\delta$ (ppm): 8.07-8.05 dd, J: 7.33, $1.46 \mathrm{~Hz}, 1 \mathrm{H}\left(-\mathrm{CH}_{\text {arom }}\right) ; 8.00-7.98$ dd, J: 7.32, $1.47 \mathrm{~Hz}, 1 \mathrm{H}\left(-\mathrm{CH}_{\text {arom }}\right) ; 7.69-7.66 \mathrm{td}, \mathrm{J}: 7.32,1.47 \mathrm{~Hz}$, $1 \mathrm{H}\left(-\mathrm{CH}_{\text {arom }}\right) ; 7.64 \mathrm{bs}, 1 \mathrm{H}(-\mathrm{NH}) ; 7.63-7.60 \mathrm{td}, \mathrm{J}: 7.33,1.46 \mathrm{~Hz}$, $1 \mathrm{H}\left(-\mathrm{CH}_{\text {arom }}\right) ; 7.50-7.48 \mathrm{~d}, \mathrm{~J}: 8.78 \mathrm{~Hz}, 2 \mathrm{H}\left(-\mathrm{CH}_{\text {arom }}\right) ; 7.06-7.03 \mathrm{t}$, J: $7.33 \mathrm{~Hz}, 2 \mathrm{H}\left(-\mathrm{CH}_{\text {arom }}\right) ; 6.98-6.96 \mathrm{~d}, \mathrm{~J}: 7.32 \mathrm{~Hz}, 1 \mathrm{H}\left(-\mathrm{CH}_{\text {arom }}\right)$; $6.94-6.92 \mathrm{~d}, \mathrm{~J}: 8.30 \mathrm{~Hz}, 4 \mathrm{H}\left(-\mathrm{CH}_{\text {arom }}\right) ; 2.88-2.85 \mathrm{t}, \mathrm{J}: 7.32 \mathrm{~Hz}, 2 \mathrm{H}$ $\left(-\mathrm{CH}_{2}-\right) ; 2.66-2.63 \mathrm{t}, \mathrm{J}: 7.81 \mathrm{~Hz}, 2 \mathrm{H}\left(-\mathrm{CH}_{2}-\right) .{ }^{13} \mathrm{C} \mathrm{NMR}(125 \mathrm{MHz}$, 
$\left.\mathrm{CDCl}_{3}\right) \delta(\mathrm{ppm}):$ 180.0, $178.9(-\mathrm{C}=\mathrm{O}) ; 142.5,140.5,138.5,134.2$ $\left(\mathrm{C}_{\mathrm{q}}\right)$; 133.5, 132.3, 132.0, 127.5, 127.3, 125.9, 125.7 (- $\left.\mathrm{CH}_{\text {arom }}\right)$; 129.6, 125.4 , 124.7, $120.2\left(\mathrm{C}_{\mathrm{q}}\right) ; 35.3,33.5\left(-\mathrm{CH}_{2}-\right)$. MS (ESI-) $\mathrm{m} /$ $z(\%): 453\left(20,[\mathrm{M}]^{+}\right), 452\left(48,[\mathrm{M}-\mathrm{H}]^{+}\right), 451\left(100,[\mathrm{M}-2 \mathrm{H}]^{+}\right)$. Anal. calcd for $\mathrm{C}_{25} \mathrm{H}_{18} \mathrm{~F}_{3} \mathrm{NO}_{2} \mathrm{~S}$ (453.48).

4.1.1.11. 2-(Phenethylthio)-3-(3-(trifluoromethyl)phenylamino)naphthalene-1,4-dione (5k). This compound was synthesized from 2-chloro-3-((3-(trifluoromethyl)phenyl)amino)naphthalene-1,4dione (3b) and 2-phenylethanethiol (4d) as a red powder by using the general procedure. Yield: $0.05 \mathrm{~g}$, mp: $93-95{ }^{\circ} \mathrm{C}, 39 \%$. FTIR (ATR) $\nu\left(\mathrm{cm}^{-1}\right): 3308(-\mathrm{NH}), 3063,3025\left(-\mathrm{CH}_{\text {arom }}\right), 2931$ $\left(-\mathrm{CH}_{\text {aliphatic }}\right), 1657(-\mathrm{C}=\mathrm{O}) .{ }^{1} \mathrm{H} \mathrm{NMR}\left(500 \mathrm{MHz}, C D C l_{3}\right) \delta(\mathrm{ppm})$ : 8.06-8.05 dd, J: 7.32, $1.46 \mathrm{~Hz}, 1 \mathrm{H}\left(-\mathrm{CH}_{\text {arom }}\right)$; 7.99-7.97 dd, J: $7.32,0.97 \mathrm{~Hz}, 1 \mathrm{H}\left(-\mathrm{CH}_{\text {arom }}\right) ; 7.68-7.65 \mathrm{td}, \mathrm{J}: 7.32,1.47 \mathrm{~Hz}, 1 \mathrm{H}$ $\left(-\mathrm{CH}_{\text {arom }}\right) ; 7.66 \mathrm{~s}, 1 \mathrm{H}(-\mathrm{NH}) ; 7.61-7.58 \mathrm{td}, \mathrm{J}: 7.80,1.46 \mathrm{~Hz}, 1 \mathrm{H}$ $\left(-\mathrm{CH}_{\text {arom }}\right)$; 7.36-7.33 t, J: $7.81 \mathrm{~Hz}, 1 \mathrm{H}\left(-\mathrm{CH}_{\text {arom }}\right)$; 7.31-7.29 d, J: $7.81 \mathrm{~Hz}, 1 \mathrm{H}\left(-\mathrm{CH}_{\text {arom }}\right) ; 7.15 \mathrm{~s}, 1 \mathrm{H},\left(-\mathrm{CH}_{\text {arom }}\right) ; 7.06-7.03 \mathrm{~m}, 3 \mathrm{H}$ $\left(-\mathrm{CH}_{\text {arom }}\right) ; 6.98-6.93 \mathrm{~m}, 3 \mathrm{H}\left(-\mathrm{CH}_{\text {arom }}\right) ; 2.86-2.83 \mathrm{t}, \mathrm{J}: 7.33 \mathrm{~Hz}$, $2 \mathrm{H}\left(-\mathrm{CH}_{2}-\right) ; 2.63-2.60 \mathrm{t}, \mathrm{J}: 7.32 \mathrm{~Hz}, 2 \mathrm{H}\left(-\mathrm{CH}_{2}-\right) .{ }^{13} \mathrm{C}$ NMR $(125$ $\left.\mathrm{MHz}, \mathrm{CDCl}_{3}\right) \delta(\mathrm{ppm}): 179.9,179.0(-\mathrm{C}=\mathrm{O}) ; 143.1,138.6,138.0$, 132.4, 129.6, 127.9, 125.4, 124.0, 119.9, 118.6, $117.8\left(\mathrm{C}_{\mathrm{q}}\right)$; 133.6, 132.0, 127.5, 127.3, 125.9, $125.7\left(-\mathrm{CH}_{\text {arom }}\right)$; 35.2, $33.6\left(-\mathrm{CH}_{2}-\right)$. MS (ESI-) $m / z(\%): 453\left(25,[\mathrm{M}]^{+}\right), 452\left(100,[\mathrm{M}-\mathrm{H}]^{+}\right)$. Anal. calcd for $\mathrm{C}_{25} \mathrm{H}_{18} \mathrm{~F}_{3} \mathrm{NO}_{2} \mathrm{~S}$ (453.48).

\subsection{In vitro antimicrobial activity}

4.2.1. Determination of minimum inhibitory concentrations (MIC). Antibacterial activities against the three Grampositive bacteria (Staphylococcus aureus ATCC 29213, Staphylococcus epidermidis ATCC 12228, and Enterococcus faecalis ATCC 29212) and four Gram-negative bacteria (Pseudomonas aeruginosa ATCC 27853, Escherichia coli ATCC 25922, Klebsiella pneumoniae ATCC 4352, and Proteus mirabilis ATCC 14153) and the antifungal activity against a yeast Candida albicans ATCC 10231 were determined by the microbroth dilutions technique using the Clinical Laboratory Standards Institute (CLSI) recommendations. ${ }^{28,29}$ Mueller-Hinton broth for bacteria and RPMI-1640 medium for the yeast strain were used as the test media. Serial two-fold dilutions ranging from $2500 \mu \mathrm{g} \mathrm{mL}{ }^{-1}$ to $0.61 \mu \mathrm{g}$ $\mathrm{mL}^{-1}$ were prepared in the medium. Inoculum was prepared using a 4-6 h broth culture for each bacteria type and 24 hours of culture of yeast strains were adjusted to a turbidity equivalent to the 0.5 McFarland standard, diluted in broth media to give a final concentration of $5 \times 10^{5} \mathrm{cfu} \mathrm{mL}^{-1}$ for the bacteria and 5 $\times 10^{3} \mathrm{cfu} \mathrm{mL}^{-1}$ for the yeast in the test tray. The trays were covered and placed into plastic bags to prevent evaporation. The trays containing Mueller-Hinton broth were incubated at $35{ }^{\circ} \mathrm{C}$ for 18-20 h, while the trays containing RPMI-1640 medium were incubated at $35{ }^{\circ} \mathrm{C}$ for $46-50 \mathrm{~h}$. The MIC was defined as the lowest concentration of compound, where the complete inhibition of visible growth can be seen. As the control, the antimicrobial effects of the solvents were investigated against the test microorganisms. According to these values of the control groups, the results were evaluated. The MIC values of the compounds are given in Table 2.
4.2.2. Determination of antibiofilm activity. Measurements of the antimicrobial susceptibilities of the bacterial and $C$. albicans biofilms were assessed using a minimum biofilm eradication concentration (MBEC) assay, which was performed with the stated mentioned techniques as in the following modifications. ${ }^{30}$ The $24 \mathrm{~h}$ biofilms were grown in a 96 well tissue culture, the microtiter plates were washed three times with 250 $\mu \mathrm{L}$ PBS solutions and air-dried. Serial two-fold dilutions ranging

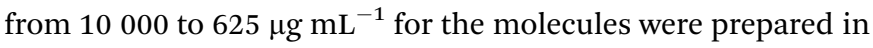
cation adjusted Mueller-Hinton broth (CAMHB). Following that, $200 \mu \mathrm{L}$ of each sample concentration were added to each corresponding well and the plates were incubated for $24 \mathrm{~h}$ at $37{ }^{\circ} \mathrm{C}$. After the incubation, the antibiotics were gently aspirated, the plates were washed, thoroughly scraped, and the contents of each well were incubated in a sonicating water bath for 5 minutes to disrupt the biofilms. $100 \mu \mathrm{L}$ samples were plated on TSA and the colonies were counted after $24 \mathrm{~h}$ of incubation at $37^{\circ} \mathrm{C}$. MBEC was defined as the lowest concentration of molecules where the microorganism failed to regrow after the exposure.

Biofilm attachment and inhibition of the biofilm formation assays were performed as in the previously described method with some further modifications. ${ }^{30} 1 / 10 \times$ MIC of molecules were added to the $24 \mathrm{~h}$ biofilm and the plates were incubated for 1,2 and $4 \mathrm{~h}$ at $37^{\circ} \mathrm{C}$; molecules at $1 \times, 1 / 10 \times$ and $1 / 100 \times \mathrm{MIC}$ concentrations were added to the $24 \mathrm{~h}$ biofilm, and plates were incubated for $24 \mathrm{~h}$ at $37{ }^{\circ} \mathrm{C}$, respectively. Six wells were used for each molecule. The positive controls were microorganisms in TSB-glucose without the molecules of interest. After the incubation, wells were washed with PBS solutions and measured at $\mathrm{OD}_{595} \mathrm{~nm}$.

4.2.3. Statistical analysis. All of the experiments were performed in two independent assays. In the determination of MIC and MBEC values, when the results were different in the both experiments, we made another test for the final result. In the assays of biofilm attachment and the inhibition of biofilm formation, results were presented as mean \pm standard deviation of two independent experiments. One way ANOVA-Bonferroni's multiple comparison test was used to compare the differences between the control and the antimicrobial treated biofilms. $P$ value $<0.001$ was considered as a statistically significant parameter.

\subsection{Cell culture and cytotoxicity assays}

Compounds $\mathbf{5 b}$ and $\mathbf{5 e}$ were assayed for in vitro cytotoxicity against the hepatocellular carcinoma (HepG2) cell line, which was kindly provided by the Department of Pharmaceutical Toxicology in the Faculty of Pharmacy at Istanbul University. HepG2 cells were grown in Eagle's Minimum Essential Medium (EMEM) (Gibco), and were supplemented with 10\% FBS (Gibco), and 100 units per $\mathrm{mL}$ penicillin $\mathrm{G}$ and 100 units per $\mathrm{mL}$ streptomycin under the humidified, $5 \% \mathrm{CO}_{2}$ atmosphere at $37{ }^{\circ} \mathrm{C}$. For the assays, the cells were seeded as $1 \times 10^{4}$ cells per well in 96 well plates and were allowed $24 \mathrm{~h}$ to ensure the attachment. Following the $24 \mathrm{~h}$, the cells were incubated either in the absence or presence of serial dilutions of test compounds for 
a further $24 \mathrm{~h}$. After the $24 \mathrm{~h}$, cell viability was determined by XTT (Xenometrix) (2,3-bis-(2-methoxy-4-nitro-5-sulfophenyl)$2 \mathrm{H}$-tetrazolium-5-carboxanilide) assay in accordance with the manufacturer's protocol. ${ }^{31}$ In each assay, three replicates for each concentration were used and this process, which used three replicates was repeated four times. The cytotoxic effects of each compound were obtained as $\mathrm{IC}_{50}$ values, which represent the molar drug concentrations required to cause $50 \%$ inhibition of cell viability.

\subsection{Docking studies}

The molecules were built using ChemSketch 12.0.1 and converted to $3 \mathrm{D}$ structure from the $2 \mathrm{D}$ structures, and further $3 \mathrm{D}$ structures were energetically minimized and saved as MDL Mol File (*.mol2). The docking was performed by Molegro Virtual Docker 2010.4.1.0 program. $^{23}$ Staphylococcus epidermidis mevalonate diphosphate decarboxylase [PDB ID: 4DPT] was taken as the target enzyme for the rationalization of the antibacterial activity. ${ }^{24}$ The polar hydrogen atoms, partial atomic charges and solvation parameters were added. The MolDock optimization search algorithm with a maximum of 100 runs was used for the calculations, while all the other parameters were kept as default. All the spatial structures were examined manually, and the best one was attained for further use.

\section{Acknowledgements}

This work was financially supported by the Scientific Research Projects Coordination Unit of Istanbul University (Project number: 53374) in the supply of the equipment and materials. We also gratefully thank to Prof. Dr Buket Alpertunga and Res. Assist. Ayşe Tarbın Jannuzzi for providing us the hepatocellular carcinoma (HepG2) cell lines and valuable suggestions from the Department of Pharmaceutical Toxicology in the Faculty of Pharmacy at Istanbul University.

\section{References}

1 (a) C. Dye, Philos. Trans. R. Soc., B, 2014, 369; (b) M. L. Cohen, Nature, 2000, 406, 762-767; (c) A. S. Fauci, Clin. Infect. Dis., 2001, 32, 675-685.

2 World Health Organization, Mortality and Global Health Estimates, Geneva, Switzerland, 2013.

3 K. F. Smith, M. Goldberg, S. Rosenthal, L. Carlson, J. Chen, C. Chen and S. Ramachandran, J. R. Soc., Interface, 2014, 11, 20140950.

4 World Health Organization, Global Tuberculosis Control, Geneva, Switzerland, 2010.

5 (a) M. N. Gwynn, A. Portnoy, S. F. Rittenhouse and D. J. Payne, Ann. N. Y. Acad. Sci., 2010, 1213, 5-19; (b) D. Sanglard, Curr. Opin. Microbiol., 2002, 5, 379-385; (c) M. L. Cohen, Science, 1992, 257, 1050-1055; (d) H. S. Gold and R. C. Moellering Jr, N. Engl. J. Med., 1996, 335, 14451453.

6 (a) A. R. M. Coates and Y. Hu, Br. J. Pharmacol., 2007, 152, 1147-1154; (b) K. Lewis, Nature, 2012, 485, 439-440.
7 (a) A. Riffel, L. F. Medina, V. Stefani, R. C. Santos, D. Bizani and A. Brandelli, Braz. J. Med. Biol. Res., 2002, 35, 811-818; (b) C. K. Ryu, R. E. Park, M. Y. Ma and J. H. Nho, Bioorg. Med. Chem. Lett., 2007, 17, 2577-2580; (c) V. K. Tandon, H. K. Maurya, D. B. Yadav, A. Tripathi, M. Kumar and P. K. Shukla, Bioorg. Med. Chem. Lett., 2006, 16, 5883-5887; (d) V. K. Tandon, H. K. Maurya, M. K. Verma, R. Kumar and P. K. Shukla, Eur. J. Med. Chem., 2010, 45, 2418-2426.

8 (a) C. K. Ryu, J. A. Choi and S. H. Kim, Arch. Pharmacal Res., 1998, 21, 440-444; (b) V. K. Tandon, H. K. Maurya, N. N. Mishra and P. K. Shukla, Eur. J. Med. Chem., 2009, 44, 3130-3137; (c) V. K. Tandon, D. B. Yadav, H. K. Maurya, A. K. Chaturvedi and P. K. Shukla, Bioorg. Med. Chem., 2006, 14, 6120-6126.

9 V. K. Tandon, H. K. Maurya, A. Tripathi, G. B. ShivaKeshava, P. K. Shukla, P. Srivastava and D. Panda, Eur. J. Med. Chem., 2009, 44, 1086-1092.

10 R. F. Silver and H. L. Holmes, Can. J. Chem., 1968, 46, 18591864.

11 I. Oeriu, Biokhimiia, 1963, 28, 380-383.

12 B. Prescott, J. Med. Chem., 1969, 12, 181-182.

13 E. M. Hodnett, C. Wongwiechintana, W. J. Dunn 3rd and P. Marrs, J. Med. Chem., 1983, 26, 570-574.

14 N. G. Clark, Pestic. Sci., 1984, 15, 235-240.

15 J. Benites, J. A. Valderrama, K. Bettega, R. C. Pedrosa, P. B. Calderon and J. Verrax, Eur. J. Med. Chem., 2010, 45, 6052-6057.

16 S. V. Druzhinin, E. S. Balenkova and V. G. Nenajdenko, Tetrahedron, 2007, 63, 7753-7808.

17 B. S. Samant and C. Chakaingesu, Bioorg. Med. Chem. Lett., 2013, 23, 1420-1423.

18 V. K. Tandon, H. K. Maurya, D. B. Yadav, A. Tripathi, M. Kumar and P. K. Shukla, Bioorg. Med. Chem. Lett., 2006, 16, 5883-5887.

19 A. F. Tuyun, N. Bayrak, H. Yildirim, N. Onul, E. M. Kara and B. O. Celik, J. Chem, 2015, 645902.

20 Website: http://www.ibmc.msk.ru/PASS.

21 (a) V. V. Poroikov, D. A. Filimonov, Y. V. Borodina, A. A. Lagunin and A. Kos, J. Chem. Inf. Comput. Sci., 2000, 40, 1349-1355; (b) V. V. Poroikov and D. A. Filimonov, J. Comput.-Aided Mol. Des., 2002, 16, 819-824; (c) A. Geronikaki, E. Babaev, J. Dearden, W. Dehaen, D. Filimonov, I. Galaeva, V. Krajneva, A. Lagunin, F. Macaev, G. Molodavkin, V. Poroikov, S. Pogrebnoi, V. Saloutin, A. Stepanchikova, E. Stingaci, N. Tkach, L. Vlad and T. Voronina, Bioorg. Med. Chem., 2004, 12, 6559-6568; (d) A. Geronikaki, A. Lagunin, V. Poroikov, D. Filimonov, D. Hadjipavlou-Litina and P. Vicini, $S A R$ QSAR Environ. Res., 2002, 13, 457-471; (e) R. K. Goel, V. Kumar and M. P. Mahajan, Bioorg. Med. Chem. Lett., 2005, 15, 2145-2148; (f) G. K. Gupta, V. Saini, R. Khare and V. Kumar, Med. Chem. Res., 2014, 23, 4209-4220; $(g)$ A. Kumar, P. Lohan, D. K. Aneja, G. K. Gupta, D. Kaushik and O. Prakash, Eur. J. Med. Chem., 2012, 50, 81-89.

22 (a) R. M. Donlan and J. W. Costerton, Clin. Microbiol. Rev., 2002, 15, 167; (b) P. Jorge, A. Lourenco and M. O. Pereira, Biofouling, 2012, 28, 1033-1061. 
23 R. Thomsen and M. H. Christensen, J. Med. Chem., 2006, 49, 3315-3321.

24 (a) M. L. Barta, D. A. Skaff, W. J. McWhorter, T. J. Herdendorf, H. M. Miziorko and B. V. Geisbrecht, J. Biol. Chem., 2011, 286, 23900-23910; (b) D. A. Skaff, W. J. McWhorter, B. V. Geisbrecht, G. J. Wyckoff and H. M. Miziorko, Arch. Biochem. Biophys., 2015, 566, 1-6.

25 (a) D. V. Krepkiy and H. M. Miziorko, Biochemistry, 2005, 44, 2671-2677; (b) D. Krepkiy and H. M. Miziorko, Protein Sci., 2004, 13, 1875-1881; (c) N. E. Voynova, Z. J. Fu, K. P. Battaile, T. J. Herdendorf, J. J. P. Kim and H. M. Miziorko, Arch. Biochem. Biophys., 2008, 480, 58-67.

26 N. P. Buu-Hoi, R. Royer and M. Hubert-Habart, Recl. Trav. Chim. Pays-Bas, 1954, 73, 188-192.
27 A. Mital, M. Sonawane, S. Bindal, S. Mahlavat and V. Negi, Der Pharma Chem., 2010, 2(3), 63-73.

28 Clinical and Laboratory Standards Institute, Reference Method for Broth Dilution Antifungal Susceptibility Testing of Yeasts, CLSI, Wayne, PA, 2th edn, 1997, Approved Standard M27-A2.

29 Clinical and Laboratory Standards Institute, Methods for dilution antimicrobial susceptibility tests for bacteria that grow aerobically, CLSI, Wayne, PA, 7th edn, 2006, Approved standard M7-A7.

30 E. Mataraci and S. Dosler, Antimicrob. Agents Chemother., 2012, 56, 6366-6371.

31 http://www.aniara.com/Resources/Xenometrix-Literature.aspx. 